\title{
Poly (ADP-ribose) polymerase (PARP) inhibitors as chemosensitizing compounds for the treatment of drug resistant cancers
}

Silpa Narayanan ${ }^{1}$, Qiu-Xu Teng ${ }^{1}$, Jagadish Koya ${ }^{1}$, Jingquan Wang ${ }^{1}$, Yehuda G. Assaraf ${ }^{2}$, Charles R. Ashby Jr ${ }^{1, *}$ and Zhe-Sheng Chen $^{1, *}$

\author{
${ }^{1}$ Department of Pharmaceutical Sciences, College of Pharmacy and Health Sciences, St. John's University, Queens, NY, \\ 11439, USA \\ 2 The Fred Wyszkowski Cancer Research Laboratory, Department of Biology, Technion-Israel Institute of Technology, Haifa, \\ 3200003, Israel \\ *Correspondence: ashbyc@stjohns.edu (Charles R. Ashby Jr); chenz@stjohns.edu (Zhe-Sheng Chen)
}

DOI:10.31083/i.jmcm.2019.03.0303

This is an open access article under the CC BY 4.0 license (https://creativecommons.org/licenses/by/4.0/).

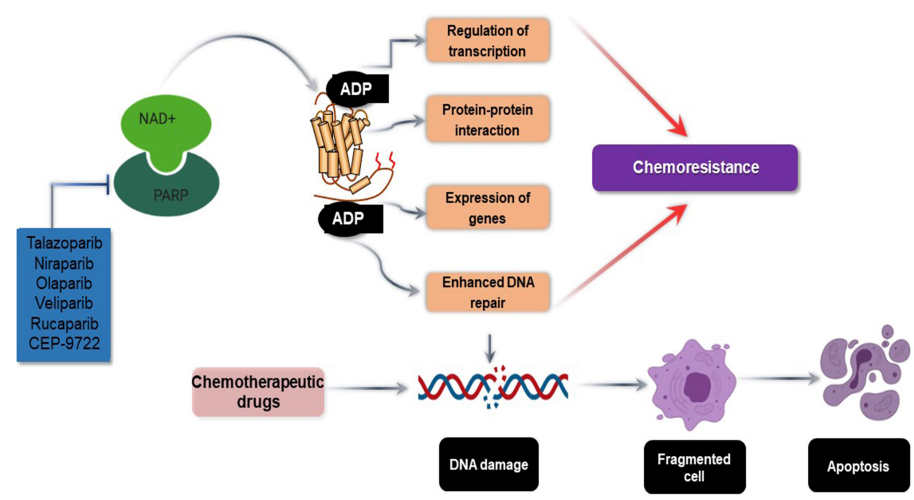

Poly (ADP-ribose) polymerase (PARP) proteins mediate various cellular processes such as DNA repair, regulation of transcription, protein-protein interaction, expression of inflammatory genes and programmed cell death. PARP proteins have a key role in DNA repair and recent findings have established the role of PARP inhibitors as potent chemotherapeutic drugs. Among the 18 members, PARP1 and PARP2 have been identified as the main targets for the development of pharmacological inhibitors to enhance the cytotoxic efficacy of established anticancer drugs. Furthermore, certain PARP1 and PARP2 inhibitors are being used in combination with other drugs for the treatment of various types of cancer. In different drug resistant cancer cell types, PARP inhibitors have been identified as compounds that reverse the resistance to topoisomerase inhibitors, DNA alkylating and methylating drugs by enhancing the DNA damage induced by these agents. In BRCA mutant cells, with abnormal homologous recombination (HR) repair mechanism, BER (Base Excision Repair Pathway) is responsible for survival of the cells. PARP enzymes play a major role in BER and PARP inhibitors effectively target BRCA mutant cells sparing normal cells via the concept of synthetic lethality, producing minimal toxicity to PARP inhibitors also have a significant role in treating pan- creatic adenocarcinoma and castration-resistant prostate cancer. The aim of the current paper is to provide a review on PARP inhibitors and their application in the treatment of various cancer cells which are resistant to standard chemotherapeutic drugs.

Keywords

Cancer; chemotherapy; drug resistance; PARP inhibitors; DNA repair; sensitizing agents; overcoming chemoresistance

\section{Introduction}

Cancer is the abnormal growth of cells due to a dysregulation of cell proliferation [1, 2, 3]. Malignant cells from the primary tumor readily undergo metastasis and invade other tissues and distant organs [4, 5, 6, 7]. The tumor cell microenvironment has a significant impact on the progression and metastasis of human cancer cells $[8,9,10]$. Numerous studies indicate that the abnormal growth and proliferation of cancer cells results from gene mutations, genetic disorders, angiogenesis, tissue invasion, lack of response to anti-apoptotic signals and evasion from immune response [2, 11]. One of the mainstays for the therapy of several types of cancer is chemotherapy [12, 13, 14]. Chemotherapeutic drugs achieve their cytotoxic activity via distinct inhibitory mechanisms including for example: 1) DNA alkylation [15]; 2) Inhibition of DNA replication [16, 17]; 3) Blocking the response to growth and proliferation signals $[18,19]$; 4) Inhibition of microtubule assembly and disruption of mitosis [20]; 5) Inducing apoptosis [21]; and 6) Augmenting the immune response to tumors $[22,23]$. However, it is well established that the efficacy of anticancer drugs can be attenuated or abrogated by the development of multiple mechanisms of drug resistance $[24,25,26,27,28,29,30]$. Consequently, there is a burning need to develop novel drugs that can overcome drug resistant cancers [31, 32]. One potential class of compounds that may be useful in treating certain types of drug resistant cancers are inhibitors of the enzyme poly (ADP-ribose) polymerase (PARP).

The poly (ADP-ribose) polymerase (PARP) family of enzymes 
catalyzes the posttranslational ribosylation of proteins by utilizing $\mathrm{NAD}^{+}$as a substrate and thereby target proteins undergo monoor polyADP ribosylation (PARylation) [33, 34]. The ADP-ribose moiety is negatively charged and after addition to the target proteins, it produces structural and functional changes [35, 36, 37]. The PARP enzyme was first characterized in 1963 [38] and currently 18 distinct protein members have been identified in this family $[34,39,40]$. PARP is a multidomain enzyme [41, 42, 43]. The $\mathrm{C}$ terminus of PARP contains the catalytic site and is highly conserved, whereas the $\mathrm{N}$ terminus has a variable and regulatory motif, a ubiquitin binding site and zinc fingers [44, 45]. Numerous studies indicate that PARP plays a major role in mediating cellular processes such as DNA repair, regulation of transcription, protein-protein interaction, expression of inflammatory genes and programmed cell death [46, 47, 48]. PARP is a bona fide target for the advancement of drugs for the treatment of breast, ovarian and prostate cancer $[40,49,50]$. PARP1 and PARP2 are known as polyADP ribose transferases because they catalyze the transfer of ADP-ribosyl to target proteins [51, 52]. PARP enzymes have a very short half-life (i.e., $<1$ minute) $[53,54]$ and they are biotransformed and inactivated by the enzymes polyglycohydrolase, ADP-ribosyl ligase and ADP-ribosyl-acceptor hydrolase$3[46,55]$. PARPs are primarily active in the nucleus, and typically have low activity in the cytoplasm [56, 57].

The current PARP inhibitors target PARP1 and PARP2 and there are at least 42 compounds known to inhibit these enzymes, 4 inhibitors of which (i.e., olaparib, rucaparib, niraparib and talazoparib) are approved by the United States Food and Drug Administration (FDA) for the treatment of various human malignancies $[58,59,60,61]$. PARP1 plays a vital role in repairing DNA single strand breaks (SSB), which are caused by oxidative stress through the base excision repair/SSB repair (BER/SSBR) pathway [62]. PARP1 has three domains: a DNA binding domain, a catalytic domain and an auto-modification domain [35, 63, 64]. The DNA binding domain interacts with damaged DNA segments and has three zinc finger motifs that confines PARP1 to the nucleus $[65,66]$. Zinc finger 2 has a high affinity for DNA fragments, whereas zinc fingers 1 and 3 mediate DNA-dependent PARP1 activation $[67,68]$. The automodification domain dissociates the protein from the DNA substrate [42, 69] and the catalytic domain facilitates the binding of $\mathrm{NAD}^{+}$, thereby catalyzing ADP ribosylation of target proteins [35, 48]. PARP 1 and PARP2 are structurally similar in many aspects except that PARP 2 does not have zinc fingers and has a short N-terminal DNA binding domain [70]. PARP 2 was first shown to be in the cells of PARP1 knockout mice that generated an ADP-ribose polymer from $\mathrm{NAD}^{+}$in response to DNA damage [71]. Since the discovery of PARP1 and PARP2, a family of 17 proteins has been identified that are similar to the catalytic domain of PARP1, but only PARP3, Vault PARP as well as PARP 5a and 5b (also known as Tankyrases 1 and 2, respectively) have been shown to have ADP-ribose polymerization activity $[72,73]$.

As a result of their role in cellular processes that are involved in cancer, specific PARP enzymes have been investigated as targets for novel anticancer drugs [40, 74, 75]. Dysregulation of cell proliferation, DNA repair and cell cycle induce tumorigenesis and are regulated by the PARP family of enzymes $[52,76]$. For ex- ample, if single stranded DNA breaks occur, PARP 1 and PARP 2 are promptly activated and rapidly bind to the DNA damage site, where they activate the DNA repair process [44, 77]. The inhibition of PARP by small molecules has been shown to increase the efficacy of chemotherapy and radiotherapy in certain types of cancers $[78,79,80]$. Indeed, PARP inhibitors increase the efficacy of cytotoxic drugs including: 1) Compounds that methylate DNA such as temolozolomide, 2) topoisomerase 1 inhibitors including irinotecan and topotecan, as well as 3 ) ionizing radiotherapy [81, 82, 83]. Numerous studies have reported that defective DNA repair pathways can enhance tumorigenesis [84, 85, 86]. Recent studies have shown that specific types of tumor cells with a defective homologous recombination (HR) repair pathway are very sensitive to certain PARP inhibitors [87, 88]. For example, BRCA1/2-deficient cancer cells are more sensitive to PARP inhibition, which causes decreased base excision repair (BER), leading to persistent DNA damage, a concept called synthetic lethality (Fig. 1). As under normal conditions, DNA damage would be repaired via HR [89, 90, 91]. However, HR defects are not limited to BRCA-deficient tumors and other types of cancer may also be enriched by HR defects which make the PARP inhibitors suitable for treating other classes of cancers. For example, if cancer cells have somatic mutations or epigenetic silencing in any part of the HR pathway, PARP inhibitors could induce the death of these cells [91]. In addition, the activity in any other part of the HR pathway could also been monitored by other proteins [92]. Mutations in the gene that encodes for the tumor suppressor protein phosphatase and tensin homolog (PTEN) have been shown to enhance the likelihood of cancer [93]. Furthermore, PTEN deficiency can decrease HR and was successfully targeted by the PARP inhibitor olaparib [94]. There are anticancer drugs whose efficacy is due to DNA damage, which causes the cancer cell death [95]. In several of the completed preclinical studies, PARP inhibition enhance DNA damage induced by cisplatin and gemcitabine [96, 97, 98]. The efficacy of such drugs can be attenuated or abolished by activation of the cellular DNA repair pathways [99]. Furthermore, these pathways can be upregulated in tumors, resulting in drug resistance [100]. PARP1 plays a role in the removal and repair of DNA single strand breaks caused by ionizing radiation, methylating and alkylating agents, topoisomerase I inhibitors and other cytotoxic drugs that damage DNA such as bleomycin [81, 83, 96]. Therefore, drugs that inhibit PARP1 can enhance the antitumor activity of chemotherapeutic drugs which inflict DNA damage [96]. Clinical studies indicate that the combination of the PARP inhibitor iniparib and CEP-9722, and the platinum drugs, carboplatin and cisplatin, respectively, significantly improves the prognosis in breast cancer patients, indicating that PARP inhibitors enhance the efficacy of drugs that produce DNA damage [80, 96, 101].

Finally, PARP inhibitors can also be used to treat sporadic, high-grade serous ovarian cancer (HGS-OC) and additional types of cancers which also have DNA repair deficiencies, including endometrial, pancreatic, and prostate and cancer [78, 102, 103, 104]. In this review, we outline the different PARP inhibitors and their mechanisms in cancer treatment (Table 1); their structures are depicted in Fig. 2. 


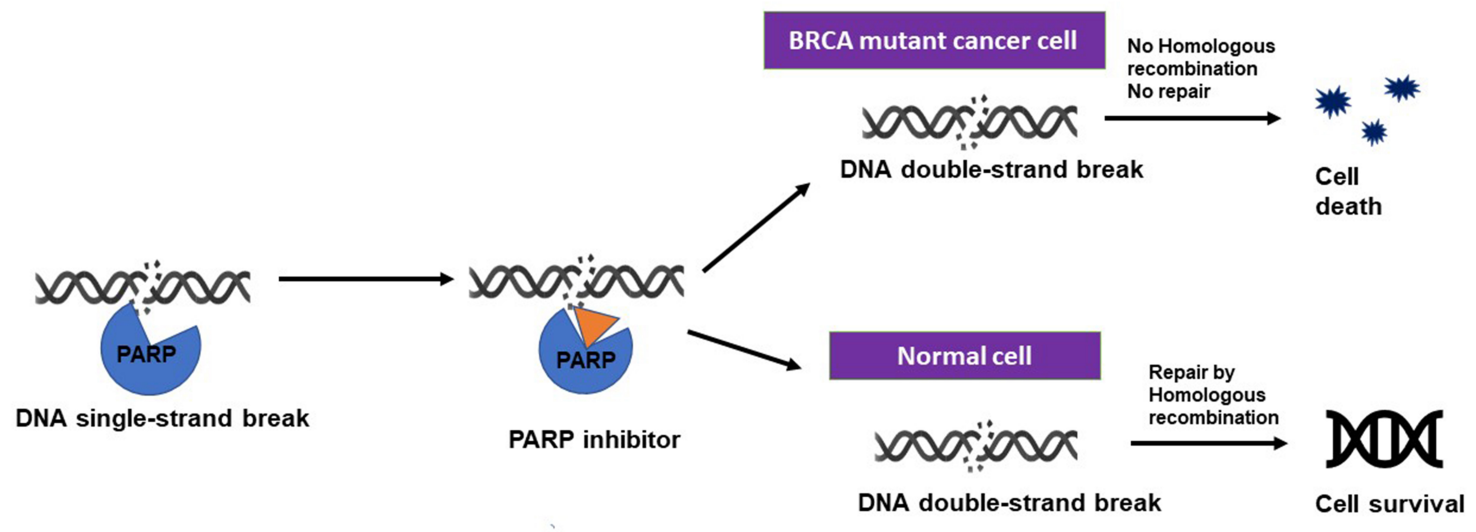

Figure 1. Synthetic lethality of Poly (ADP-ribose) polymerase (PARP) inhibitors. PARP enzymes play a vital role in DNA damage repair. DNA damage can be repaired via homologous repair (HR) mechanisms in normal cells. BRCA mutant tumors are inherently defective in HR repair. PARP inhibitors cause DNA damage which cannot be repaired by HR mechanisms, thereby cause the selective apoptosis of these cells.<smiles>Cn1ncnc1C1c2n[nH]c(=O)c3cc(F)cc(c23)N[C@H]1c1ccc(F)cc1</smiles>

Talazoparib

D<smiles>C[C@H](c1nc2c(C(N)=O)cccc2[nH]1)C1CCCN1</smiles>

Veliparib<smiles>NC(=O)c1cccc2cn(-c3ccc(C4CCCNC4)nc3)cc12</smiles>

Niraparib

E<smiles>CNCc1ccc(-c2[nH]c3cc(F)cc4c3c2CCNC4=O)cc1</smiles>

Rucaparib<smiles></smiles>

Olaparib

$\mathrm{F}$<smiles></smiles>

CEP-9722

Figure 2. The structures of PARP inhibitors that sensitize cancer cells to conventional chemotherapeutic drugs.

\section{PARP inhibitors-Detailed description}

\subsection{Talazoparib}

Talazoparib's inhibitory activity depends on its unique binding interactions with the $\mathrm{NAD}^{+}$site as well as the active enantiomer (trans) configuration, which is responsible for $\pi$ stacking and hydrogen-bonding interactions mediated by water between the fluorophenyl and 1,2,4-triazole groups of talazoparib with Tyr889 and Tyr896 residues of PARP1 [105]. Talazoparib (5-fluoro-8-(4-fluorophenyl)-9-(1-methyl-1H-1,2,4triazol-5-yl)-2,7,8,9-tetrahydro-3H-pyrido[4,3,2-de] phthalazine3-one) was recently approved by the FDA for the treatment of patients with deleterious or suspected deleterious inherited BRCA germline mutations [106] and human epidermal growth factor receptor-2 (HER-2) negative breast cancer [107, 108]. Talazoparib irreversibly inhibits PARP1 and PARP2 which regulate cell cycle progression, initiation of the DNA damage response, and apoptosis $[105,109,110]$. Talazoparib traps PARP on single-stranded
DNA breaks, producing cytotoxicity [111]. PARP inhibition by talazoparib causes lethality in cancer cells with BRCA1/2 mutations due to their deficiency in HR-dependent DNA repair and the accumulation of irreversible DNA damage which induces cell death [112, 113, 114]. Furthermore, talazoparib has greater PARP inhibitory efficacy than olaparib [115], as it inhibits double stranded DNA break repair, producing alternative non-homologous end joining instead of HR [116], leading to cytotoxicity. Preclinical studies in both human and animal tumor models indicated that talazoparib had a pharmacokinetic profile suitable for progression into clinical trials [117, 118]. The oral bioavailability of talazoparib in rats was more than $40 \%$ and based on this, it was predicted that talazoparib could be administered once a day [118]. Pharmacokinetic data have been evaluated from phase I, phase II and phase III studies in cancer patients, over a dose range of 0.025-2 mg/day [119]. Talazoparib undergoes cysteine conjugation to form monodesfluoro-talazoparib, dehydrogenation, monooxidation and glu- 
Table 1. The different PARP inhibitors and their mechanisms in cancer treatment

\begin{tabular}{|c|c|c|c|c|c|}
\hline Compound & Target of interaction & FDA status & Dose & Route & Adverse effects \\
\hline Talazoparib & Inhibits PARP 1 and 2 & $\begin{array}{l}\text { Approved for advanced } \\
\text { breast cancer }\end{array}$ & $1 \mathrm{mg}$, once a day & oral & $\begin{array}{l}\text { Anemia, neutropenia and throm- } \\
\text { bocytopenia. }\end{array}$ \\
\hline Niraparib & Inhibits PARP 1 and 2 & $\begin{array}{l}\text { Approved for ovarian and } \\
\text { fallopian cancer }\end{array}$ & $300 \mathrm{mg}$, once a day & oral & $\begin{array}{l}\text { Thrombocytopenia, fatigue and } \\
\text { anemia. }\end{array}$ \\
\hline Olaparib & Inhibits PARP 1 and 2 and 3 & $\begin{array}{l}\text { Approved for advanced } \\
\text { ovarian cancer }\end{array}$ & $300 \mathrm{mg}$, twice a day & oral & Vomiting, anemia and diarrhea \\
\hline Veliparib & Inhibits PARP 1 and 2 & $\begin{array}{l}\text { Phase III for breast and } \\
\text { ovarian cancer }\end{array}$ & $120 \mathrm{mg}$, twice a day & oral & $\begin{array}{l}\text { Grade } 2 \text { nausea, vomiting, fatigue, } \\
\text { and anemia }\end{array}$ \\
\hline Rucaparib & Inhibits PARP 1,2 and 3 & $\begin{array}{l}\text { Approved for advanced } \\
\text { ovarian cancer }\end{array}$ & $600 \mathrm{mg}$, twice a day & oral & $\begin{array}{l}\text { Anemia, nausea, vomiting, throm- } \\
\text { bocytopenia, shortness of breath. }\end{array}$ \\
\hline CEP-9722 & Inhibits PARP 1 and 2 & $\begin{array}{l}\text { Phase I for urothelial can- } \\
\text { cer }\end{array}$ & $150-1000 \mathrm{mg}$, once a day & oral & $\begin{array}{l}\text { Neutropenia, leukopenia, and ane- } \\
\text { mia }\end{array}$ \\
\hline
\end{tabular}

curonidation and is excreted primarily in the urine in its parent form $[106,119]$. The mean plasma half-life is approximately $90 \mathrm{hr}$ in cancer patients [106]. A dose of $1 \mathrm{mg} /$ day is recommended in patients to reduce the occurrence of adverse effects, but the dose must be decreased in patients with moderate and severe renal impairment $[106,119]$. In vitro, talazoparib does not significantly inhibit or induce hepatic CYP1A2, CYP2C9, CYP2C19, CYP2D6 and CYP3A4 [108].

Talazoparib has been considered as monotherapy for neoadjuvant patients [120]. A study with 13 breast cancer patients with a germline BRCA mutation that received talazoparib as monotherapy for 2 months before neoadjuvant therapy (anthracycline and taxane based chemotherapy \pm carboplatin) and surgery displayed a significant decrease (approximately 88\%) in tumor volume [107]. Another study (NCT02282345) with 20 advanced breast cancer patients with a germline BRCA mutation indicated that administration of talazoparib 6 months prior to surgery produced a complete pathologic response [113]. The combinations of talazoparib with other anticancer drugs has yielded significant therapeutic efficacy. Talazoparib, when used in combination with temozolomide, produced a 59-, 35- and 1500-fold greater cytotoxic efficacy in Lovo cells (colon cancer cells) compared to monotherapy treatment with the PARP inhibitors olaparib, rucaparib and veliparib, respectively [105]. In BRCA-deficient breast cancer patients, combination therapy of talazoparib, with cisplatin or temozolomide, produced significant positive response rates up to $73 \%$ [121]. Previously, talazoparib was reported to be more efficacious than olaparib or talazoparib as a radiosensitizer in glioblastoma stem cells in vitro [122]. Furthermore, talazoparib (12.5 nM), compared to veliparib and olaparib, displayed greater efficacy in sensitizing the olaparib-resistant breast cancer cell line, CAL51 by targeting genes involved in Homologous repair/Double stranded DNA break repair pathways such as BRCA1/2(breast cancer resistance protein), SHFM1 (split hand/foot malformation gene), PKNB (protein kinase B gene), PALB2 (Partner and localizer of BRCA2 gene), ATM (Ataxia-Telangiesctasia gene), ATR(AtaxiaTelangiesctasia and Rad3 related gene), CHEK1 (Checkpoint kinase 1 gene), FANCM (Fanconi anemia complementation group M), FANCA (Fanconi anemia complementation group A) etc. [118]. The common untoward toxicity produced by talazoparib was anemia, neutropenia and thrombocytopenia, which can be minimized by a dose reduction $[113,114]$.

\subsection{Niraparib}

Niraparib (2-\{4-[(3S)-piperidin-3-yl]phenyl $\}-2 \mathrm{H}-2 \mathrm{H}$-indazole -7-carboxamide) was approved by U.S. FDA on March 2017 and EMA for the maintenance treatment of recurrent epithelial ovarian and fallopian tube or primary peritoneal cancer patients [123]. Niraparib not only blocks the DNA repair mechanism by inhibiting the BER pathway, but also traps PARP-1 and PARP-2 at the sites of DNA damage, producing cytotoxicity [124, 125]. Niraparib has displayed higher PARP binding affinities as it mimics the structure of the amide group of nicotinamide binding domain and is responsible for three important hydrogen bonds to the hydroxyl group of Ser904 and the amide backbone of Gly863, along with the pyridyl ring which is responsible for $\pi-\pi$ interactions with Tyr907 [125].

Pre-clinical data indicate that niraparib $(1 \mu \mathrm{M})$ augments the effect of radiation therapy in tumor cell-based and murine xenograft models, independent of p53 status [126]. In human derived lung and breast cancer xenograft models, including a triple negative breast cancer xenograft, niraparib $(50 \mathrm{mg} / \mathrm{kg}$, orally) sensitized the xenografts to radiation therapy in a p53-independent manner [127].

A phase I dose escalation trial has shown that niraparib does not produce significant adverse effects up to a maximum dose of $300 \mathrm{mg} /$ day in patients harboring a BRCA mutation and in patients with sporadic cancers [128]. Niraparib is primarily biotransformed by hepatic carboxylesterase which produces inactive drug metabolites that are glucuronidated and excreted into the urine and feces [129, 130]. Similar to talazoparib, naraparib does not significantly interact with cytochrome P450 hepatic enzymes [131]. Niraparib has a mean half-life of $36 \mathrm{~h}$ following multiple daily doses, with an oral bioavailability of $73 \%$ [60]. In humans, at steady state levels, niraparib has a higher volume of distribution (approximately $1500 \mathrm{~L}$ ) compared to olaparib (approximately $158 \mathrm{~L}$ ) [132, 133]. Niraparib crosses the blood-brain barrier (BBB) and its levels in the brain are greater than olaparib, as it is expelled to a lower extent than olaparib by the ABC transporters BCRP and P-gp in the BBB [134].

The results of the PRIMA trial indicate that niraparib can be a first line treatment for longer periods of PFS (progression - free 
survival) in patients diagnosed with advanced recurrent ovarian cancer [135]. Niraparib, when used in combination with irinotecan, potentiated the cytotoxic effects of irinotecan in microsatellite instable (MSI) and stable (MSS) colorectal cancer models in vitro [136]. Niraparib, when combined with cyclophosphamide, displayed a significant efficacy in treating triple negative breast cancer patient-derived xenograft human models [137]. Niraparib is efficacious in inhibiting the growth of tumors in patient-derived xenograft models, regardless of the BRCA or homologous recombination deficiency (HRD) status [132, 138]. During the phase III NOVA trial, adverse effects commonly reported for niraparib were thrombocytopenia, fatigue and anemia, which can be minimized by adjusting the dose [139]. The ongoing phase I, II and III clinical trials (NCT02854436, NCT03748641, NCT03431350, respectively) will determine the efficacy of niraparib alone or in combination with drugs like abiraterone, prednisolone and JNJ637283 (an immune checkpoint inhibitor), for the treatment of prostate cancer [50].

\subsection{Olaparib}

Olaparib(4-(3-\{[4-(Cyclopropylcarbonyl)-1piperazinyl]carbonyl \}-4-fluorobenzyl)-1(2H)-phthalazinone) was the first drug from the family of PARP inhibitors that was approved by the FDA in 2014 for the treatment of ovarian cancer [140]. It inhibits PARP1 and PARP 2 which results in double-stranded DNA breaks that produces apoptosis in cancer cells [140, 141]. Olaparib contains oxygen atoms which forms hydrogen bonds with backbone atoms in the catalytic domain of Arginine and also water mediated hydrogen bonds with aspartic acid and Van der Waals Force interaction with aliphatic side chain of glutamic acid in the regulatory domain [142]. Olaparib was approved both in Europe and USA as maintainence treatment in platinum-sensitive ovarian cancer patients, independent of their BRCA1/2 mutation status [143].

Olaparib can be administered orally at daily doses amounting 200-600 mg, depending on the renal function of the patient [141]. Its peak plasma concentration occurs 1-3 hours after administration [144] and it has a terminal elimination half-life of $11.9 \mathrm{~h}$ following a $400 \mathrm{mg}$ dose [141]. Olaparib has an apparent volume of distribution $167 \mathrm{~L}$ and is primarily metabolized in the liver by dehydrogenation and oxidation, and it undergoes glucuronide and sulfide conjugation [144]. Olaparib is primarily excreted unchanged in the urine and consequently, olaparib's renal clearance is decreased in patients with diminished renal function [141]. Furthermore, in patients with mild (GFR $=51-80 \mathrm{~mL} / \mathrm{min}$ ) to moderate renal impairment $(\mathrm{GFR}=31-50 \mathrm{ml} / \mathrm{min})$, there was a decrease in the volume of distribution and terminal half-life compared to patients with normal renal function $[145,146]$. The most common adverse events of any grade reported following treatment with olaparib were nausea, fatigue, vomiting, anemia and diarrhea, although severe grade 3 or 4 anemias have been reported in some patients and this could be managed by a dose reduction [147, 148]. Olaparib increases the efficacy of the platinum drugs cisplatin and carboplatin, in both in vitro and in vivo models of BRCA-deficient mouse mammary cancers [149]. Olaparib also increased the efficacy of cisplatin in BRCA-deficient mouse mammary cell lines [150]. When used as a monotherapy, olaparib has been shown to produce antitumor efficacy in BRCA-deficient mouse mod- els [151]. Data from a Phase I study (NCT00494442)has shown that olaparib alone has antitumor efficacy in pretreated BRCA1 and BRCA2-deficient patients with recurrent ovarian cancer [152]. Phase III trials with olaparib have shown a significant increase in the quality of life and a longer PFS in: 1) ovarian cancer patients with a germline BRCA1/2 mutation who were previously treated with platinum chemotherapy [153] and 2) patients with platinumsensitive relapsed ovarian cancer [143, 148].

Olaparib has been reported to have efficacy in the treatment of castration-resistant prostate cancer (CRPC) based on the results of the TOPARP-A trial where 16 patients were previously treated with abiraterone, enzalutamide or cabazitaxel, followed by olaparib at $400 \mathrm{mg}$ twice a day until the primary response rate (decrease in PSA) was observed. The results indicated that there is a significant decrease in PSA levels and decreased circulating tumor cell counts which reflect its antitumor activity [154]. Another trial namely POLO, indicated that olaparib maintenance treatment of $300 \mathrm{mg}$ twice a day for 4 to 8 weeks, produced a substantial (PFS) in metastatic pancreatic cancer patients with BRCA mutations who had not benefited from platinum-based chemotherapy [155]. A phase I/II trial that was designed to evaluate the effectiveness of olaparib 100-200 mg twice a day for a 21-day cycle in combination with temozolomide in patients who were formerly treated for small cell lung cancer. There was a significant increase in PFS $[156,157]$. The data form the phase III trial, OlympiAD, reported that olaparib monotherapy of $300 \mathrm{mg}$ twice daily for 21 days (dose and length of treatment) in patients with HER-2 negative metastatic breast cancer and a BRCA mutation had a significant longer PFS when compared to patients treated with capecitabine, eribulin, or vinorelbine in 21-day cycles [158].

\subsection{Veliparib}

Veliparib (ABT-888) has high potency in inhibiting PARP1/2, with Ki values of 5.2 (PARP1) and 2.9 (PARP 2) nM, as determined by in vitro fluorescence assays [102]. The amide group of veliparib binds with PARP active site, and intermolecular hydrogen bonds are formed between amide bond and Gly-863/Ser-904 Moreover, veliparib also forms a $\pi-\pi$ stacking with Tyr-907 [159]. Veliparib, similar to other PARP inhibitors,: inhibits PARP1 and PARP2, which disrupts the BER mechanism and consequently induces DNA damage, resulting in induction of cellular apoptosis [160].

Veliparib alone has been reported to have limited in vitro efficacy in a panel of lung cancer cells [161]. However, in a xenograft model of SCLC (H146 and H128 cells in the flank region of 6week-old athymic nu/nu mice), the administration of $25 \mathrm{mg} / \mathrm{kg}$ i.p. of veliparib and $2.5 \mathrm{mg} / \mathrm{kg}$ i.p. of cisplatin for 4 weeks, significantly decreased tumor size compared to animals treated with cisplatin or etoposide alone [160]. Also, in vitro, veliparib (10 $\mu \mathrm{M}$ for 24 or $72 \mathrm{~h}$ ) significantly increased DNA-damage signaling (i.e., pKAP1S824, pChk1S345 and pChk2T68) in the glioblastoma multiforme cell lines T98G, U251 and U251TMZ [162].

Currently, 10 clinical studies related to veliparib have been approved by the FDA, including 6 phase III clinical trials. In April 2014, the FDA approved a phase III trial of veliparib for squamous NSCLC; however, the outcome missed the primary expectation, which was a significant increase in overall survival, PFS and objective response rate. Veliparib was also approved for a phase III 
clinical trial in $\mathrm{HER}^{-}{ }^{-}$metastatic or $\mathrm{BRCA}^{+}$breast cancer in $\mathrm{Au}-$ gust 2014, although there has been no patient recruitment. Besides the 6 phase III clinical trials mentioned above, multiple ongoing or completed phase I or II clinical trials have been approved by the FDA. A phase I trial of veliparib and metronomic cyclophosphamide [163], which focused on various types of refractory cancers (i.e., ovarian, carcinoid, breast, colon, pancreas, urothelial, melanoma, sarcoma, endometrial, lymphoma and unknown type), was approved. Thirty-five patients were given $60 \mathrm{mg}$ of veliparib (orally, once daily for 21 days) and $50 \mathrm{mg}$ of cyclophosphamide (orally, once daily for 21 days) [163]. The results indicated that 6 patients had their disease stabilized for at least 6 cycles and 7 patients had partial responses. In addition, in 7 patients, there was a decrease in peripheral blood mononuclear cells (PBMCs) and an increase in phosphorylated histone (VH2AX) levels, which is a biological marker of DNA damage in circulating tumor cells. In 2015, a phase II study was performed to confirm the efficacy of combining veliparib and cyclophosphamide in patients with ovarian cancer. After oral administration $(50 \mathrm{mg} /$ day cyclophosphamide and $60 \mathrm{mg} /$ day veliparib) in a 21-day cycle, veliparib failed to improve the response rate [164].

\subsection{Rucaparib}

Rucaparib (AG014699, RubracaTM) is a small molecule PARP1, PARP2 and PARP-3 inhibitor [165]. It forms hydrogen bond interaction with Gly-863 located in the binding site of PARP1. TYR889, TYR896 and TYR907 are likely to participate in forming $\pi-\pi$ interaction with the indole core [166]. The mechanism of action of rucaparib has been previously characterized by Robillard et al [167]. Rucaparib selectively inhibited PARP1, PARP2 and PARP3, with $\mathrm{IC}_{50}$ values of $0.8,0.5$ and $28 \mathrm{nM}$, respectively. Also, in the UWB1.289 (ovarian cancer) cell line, rucaparib decreased poly-ADP ribosylation in a concentrationdependent manner, with an $\mathrm{IC}_{50}$ value of $2.8 \mathrm{nM}$, and increased DNA damage and apoptosis [167]. Oral rucaparib was approved by the FDA for the treatment of advanced ovarian cancer with deleterious BRCA mutations [168]. The FDA has approved 51 clinical trials with rucaparib for multiple cancer types including ovarian, prostate, urothelial, cervical, lung and breast (clinicaltrials.gov). Additionally in a phase II trial of rucaparib in relapsed highgrade ovarian cancer patients with platinum-sensitive tumors, the risk of progression during treatment with rucaparib (oral, 600 $\mathrm{mg}$, twice daily for a 28-day cycle) was significantly reduced in BRCA-mutant and BRCA-wild-type groups [169]. Subsequently, a phase III clinical trial with rucaparib in recurrent ovarian carcinoma after treatment with platinum therapy indicated that the patients treated with rucaparib had a significantly greater median progression-free survival time in patients with a BRCA-mutant carcinoma (5.4 months in placebo group versus 16.6 months in the rucaparib group) [170]. The efficacy of rucaparib has also been evaluated in patients with metastatic melanoma who were receiving temozolomide [59]. The results showed that the administration of temozolomide $\left(150-200 \mathrm{mg} / \mathrm{m}^{2} /\right.$ day) and a PARP inhibitory dose $\left(12 \mathrm{mg} / \mathrm{m}^{2} /\right.$ day $)$ of rucaparib increased PFS compared to historical controls [171]. At the end of 2019, two new clinical studies were approved by the FDA: a phase I study involving the treatment of metastatic castration resistant prostate cancer with rucaparib, enzalutamide and abiraterone (Dec, 2019) and a phase II study of rucaparib in patients with solid tumors, prostate, breast, ovarian, fallopian tube and peritoneal with a mutation in one or more genes, including breast cancer gene (BRCA1/2), partner and localizer of BRCA2 gene (PALB2), DNA double strand repair gene (RAD51B/C/D), BRCA1-associated ring domain gene (BARD1), BRCA1-interacting protein gene (BRIP1), Fanconi anaemia complementation group gene (FANCA), nibrin gene (NBN) with deleterious mutations in homologous recombination repair (HRR) genes (clinicaltrial.gov). These two studies are newly approved and have not started recruitment yet.

\subsection{CEP-9722}

CEP-9722 (11-methoxy-2-((4-methylpiperazin-1-yl)methyl)4,5,6,7-tetrahydro-1H-cyclopenta[a]pyrrolo[3,4-c]carbazole$1,3(2 \mathrm{H})$-dione), a pro-drug which is biotransformed to another compound, CEP-8983 (11-methoxy-4,5,6,7-tetrahydro-1Hcyclopenta[a]pyrrolo[3,4-c]carbazole-1,3(2H)-dione) and it is an inhibitor of PARP1 and PARP2 [172]. CEP-9722 is rapidly metabolized to CEP-8983 in less than 5 minutes [172]. The in vitro study shown that CEP-9722 $(0.1-10 \mu \mathrm{M})$ increased the number of DNA single-stranded breaks, inducing cell instable and apoptosis [172]. As this compound is a new drug in early stages of development, the published studies focus primarily on clinical efficacy and have not focused on investigation of the interaction of CEP-9722 with its PARP target [172]. Although there have been several pre-clinical studies and three clinical trial studies performed to evaluate the clinical application of CEP-9722, it remains to be approved by the U.S. FDA. In vitro, CEP-8983 increased the efficacy of certain anticancer drugs in chemoresistant tumors by prolonging the duration of DNA damage and increasing apoptosis [173, 174, 175]. However, the in vitro incubation of CEP-9722 with temozolomide or topotecan, respectively, did not increase chemotherapy-related myelotoxicity based on results from a granulocyte-macrophage colony-forming unit assay [172]. In addition, CEP-9722 alone displayed anti-tumor efficacy in human colon carcinoma HT29 cell xenografts in nude mice and in a chemoresistant rat glioblastoma RG2 cell xenografts in rats and CEP-9722 decreased the accumulation of PARP in glioma xenografts in a dose- and time-dependent manner [172].

Jian et al. (2014) investigated the effect of CEP-9722 and CEP8983 on urothelial carcinoma (UC). CEP-9722, compared to CEP8983 or cisplatin alone, produced an increase in DNA damage in the human UC cell lines RT4 and 5637 cells. CEP-9722, at 200 $\mathrm{mg} / \mathrm{kg}$ administered by oral gavage, once daily for 5 days a week for 4 weeks via oral gavage, significantly decreased tumor growth in RT4 xenografts compared to animals treated with vehicle alone. Immunohistochemistry data indicated that cleaved caspase-3 levels were significantly increased, whereas there was a decrease in the expression of CD31, the platelet cell adhesion molecule- 1 that is a biomarker of angiogenesis. The evaluation of biomarkers indicative of PARP inhibition in UC is sound because the efficacy of CEP-9722 is inversely proportional to the HRR reaction involved in DNA damage repair [176]. A phase I trial with temozolomide supported the hypothesis that CEP-9722 may cause less myelosuppression compared to all other oral PARP inhibitors [174]. In this study, 26 patients with solid tumors were treated orally with increasing doses of CEP-9722 from 150- $1000 \mathrm{mg} /$ day for 14 days, and then treated for 28-days with $1000 \mathrm{mg} /$ day of CEP-9722 and 
$150 \mathrm{mg} / \mathrm{m}^{2} /$ day temozolomide for all the treatment period. Although there were significant interpatient and intrapatient variation, the plasma levels of CEP-8983, which is the active form of CEP-9722, was used to assess the relative plasma concentration of CEP-9722. It is worth noting that the plasma concentrations of CEP-8983 were lower in patients taking drugs that may increase gastric $\mathrm{pH}$ as well as in cigarette smokers, which may result from the poor solubility of CEP-8983 in non-acidic environments and an increased metabolism of CEP-8983 due to an increased expression of CYP1A2, respectively [174]. Subsequently, the safety, efficacy and pharmacokinetic profile of CEP-9722 combined with oral temozolomide was evaluated in patients with advanced solid tumors such as breast, colorectal, and ovarian cancers. The results revealed one case of a partial response, four cases with a stable disease and 17 cases showed disease progression and CEP-9722 and temozolomide treatment was stopped at cycle 12 due to concerns about the cumulative toxicity of temozolomide [174]. As previously reported, CEP-9722 produced a lower magnitude of myelosuppression compared to other PARP inhibitors.

Awada et al., (2016) conducted a study to determine the maximum tolerable dose of CEP-9722 when combined with either gemcitabine or cisplatin in patients with advanced solid tumors. Thirty-two patients were given $75 \mathrm{mg} / \mathrm{m}^{2}$ of cisplatin and 1,250 $\mathrm{mg} / \mathrm{m}^{2}$ of gemcitabine on the first day of the study and the eighth day of the 21-day treatment cycle. However, only 18 patients who completed the first chemotherapy cycle with cisplatin and gemcitabine were treated orally with $150,200,300$, or $400 \mathrm{mg}$ of CEP9722 twice daily from the second day to the seventh day and doselimiting toxicities were evaluated. Patients were allowed to proceed with treatment until the disease progressed or the adverse toxicity was determined to be unacceptable. The median treatment range for CEP-9722 was five (1-12) cycles and no patients had dose-limiting toxicity after CEP-9722; however, 33\% of the patients stopped treatment due to adverse effects. At the end of the study, there was one patient with a complete remission, three patients with partial remission and eleven patients displayed a stable disease. Prior to the determination of the maximum tolerable dose, the study was discontinued due to significant changes in the exposure to CEP-8983 in all cohorts and toxicity with myelosuppression [96].

\section{Acquired resistance to PARP inhibitors}

There are a number of mechanisms that can produce resistance to PARP inhibitors. Mutations in BRCA1 and BRCA2 (tumor suppressor genes), predispose to various human cancers including, breast, ovarian, pancreatic and prostate cancer [177, 178]. The HR pathway is important for the repair of double-stranded DNA breaks $[179,180]$ and BRCA is a main factor in double-stranded DNA break repair via the HR mechanism [181, 182]. Inhibition of the HR pathway can induce apoptosis [183] and the efficacy of PARP inhibitors is greater in HR-deficient than in non-HR-deficient cancer cells [184]. In addition, cancer cells that lack the BRCA genes are susceptible to PARP inhibitors and the restoration of BRCA genes causes resistance to PARP inhibitors [84, 85].

Overexpression of the $\mathrm{ABC}$ transporter, $\mathrm{ABCB} 1$, in a P-gpproficient mouse model has been reported to cause a lower survival rate compared to P-gp-deficient mice which were given olaparib for 28 days [185]. This is due to due to the efflux function of the ABC transporter, ABCB1/P-gp, which extrudes PARP inhibitors from cancer cells, leading to resistance to PARP inhibitors including rucaparib or olaparib [185]. ABCB1-mediated resistance has been shown to occur in mice with BRCA1-deficient breast tumors [101]. The marked expression P-gp in A2780 ovarian cancer cells produced a 36-fold increase in the concentration of olaparib required to inhibit growth by $50 \%$ and this acquired resistance can be surmounted by ABCB1 inhibitors like verapamil [186]. The loss of the p53-binding protein 1(53BP1) has been reported to produce resistance by restoring BRCA function [187, 188, 189]. The HR pathway is inhibited by 53BP1 and the loss of 53BP1 restores the activity of BRCA- mediated HR and causes resistance to olaparib $[185,190]$. Furthermore, loss of 53BP1 produced resistance to olaparib by increasing the expression of P-gp, thereby increasing olaparib efflux, hence attenuating its cytotoxic activity [101]. It has been shown that 53BP1 is not expressed in BRCA1/2 mutated breast cancer cells [191] and the survival rate of patients with BRCA1/2 mutated breast cancer is low due to an increase in resistance to drugs that cause DNA damage, such as cisplatin and mitomycin. It has been postulated that the expression of 53BP1 could be used to ascertain the efficacy of PARP inhibitors upon treatment of BRCA1-deficient tumors [190].

PARylation is a reversible modification of the PARP enzyme and other nuclear proteins and these PAR chains formed facilitate the recruitment of DNA repair enzymes; PAR modifications turn over rapidly due to the activity of poly-(ADP-ribose) glycohydrolase (PARG) [191]. PARG catalyzes the removal of PAR chains from post-translationally modified proteins, releasing poly ADPribose [191, 192]. PARG can thus eliminate nuclear PARylation and this could nullify the function of PARP1 [193]. In an HRdeficient mouse model, loss of PARG activity induced resistance to PARP inhibitors by restoring the activity of PARP [193].

The depletion or loss of the PARP1, as well as a decrease in the affinity of PARP1 inhibitors, have been shown to produce resistance to PARP inhibitors such as olaparib [193, 194, 195]. Ovarian cancer cells, as well as tumors from patient-derived xenografts (Makvandi et al., 2018), that do not express PARP1, are resistant to olaparib. There is a positive correlation between PARP inhibitors efficacy and the level of functional PARP 1 levels [196]. Moreover, mouse embryonic stem (ES) cells with PARP 1 mutation are highly resistant $(\sim 100$-fold $)$ to olaparib than cells with wild type PARP 1 [197].

\section{Conclusions}

PARP inhibitors are a new class of drugs that improved the outcome in several cancer types. The deficiency in DNA repair mechanisms causes extensive irreversible DNA damage leading to apoptosis and PARP inhibitors have proved to target these mechanisms. This contributes to the use of clinical PARP inhibitors along with DNA damaging agents, thereby restoring cancer cell chemosensitivity to conventional drugs. PARP inhibitors have a great impact in women with ovarian cancers and in either somatic or germline BRCA1/2 mutations, they are used as a maintenance therapy and increase the overall survival rate. The present article focused on FDA approved PARP inhibitors like talazoparib, niraparib, olaparib and rucaparib and other drugs like veliparib and 
CEP-9722 which are currently undergoing clinical trials and are under extensive investigation. Because of the low toxicity profiles, they are ideal for the prolonged treatment of cancer. However, tumors can develop mechanisms of resistance to PARP inhibitors, due to occurrence of secondary mutations, increased drug efflux, decrease PARP level and loss of 53BP1 function. A better understanding of these molecular mechanisms of chemoresistance is important to for the selection of the most efficacious drug treatment. Overall, PARP inhibitors have gained a great attention for their activity in HR-deficient tumors and further research can be conducted to expand their clinical utility in various cancers.

\section{Acknowledgements}

We thank the partial support from the Department of Pharmaceutical Sciences, College of Pharmacy and Health Sciences, St. John's University and the National Institute of Health-USA (1R15GM116043-01).

\section{Conflict of interest}

The authors declare no potential conflicts of interest.

\section{References}

[1] Macconaill LE, Garraway LA. Clinical implications of the cancer genome. J Clin Oncol 2010; 28(35): 5219-5228.

[2] Fouad YA, Aanei C. Revisiting the hallmarks of cancer. Am J Cancer Res 2017; 7(5): 1016-1036.

[3] Narayanan S, Gupta P, Nazim U, Ali M, Karadkhelkar N, Ahmad M, Chen Z-S. Anti-cancer effect of indanone-based thiazolyl hydrazone derivative on colon cancer cell lines. Int J Biochem Cell Biol 2019; 110: 21-28.

[4] Lambert AW, Pattabiraman DR, Weinberg RA. Emerging biological principles of metastasis. Cell 2017; 168(4): 670-691.

[5] Cominetti MR, Altei WF, Selistre-de-Araujo HS. Metastasis inhibition in breast cancer by targeting cancer cell extravasation. Breast Cancer 2019; 11: 165-178.

[6] Yang Y, Zheng H, Zhan Y, Fan S. An emerging tumor invasion mechanism about the collective cell migration. Am J Transl Res 2019; 11(9): 5301-5312.

[7] Goldenberg MM. Trastuzumab, a recombinant DNA-derived humanized monoclonal antibody, a novel agent for the treatment of metastatic breast cancer. Clin Ther 1999; 21(2): 309-318.

[8] Wang M, Zhao J, Zhang L, Wei F, Lian Y, Wu Y, Gong Z, Zhang S, Zhou J, Cao K, Li X, Xiong W, Li G, Zeng Z, Guo C. Role of tumor microenvironment in tumorigenesis. J Cancer 2017; 8(5): 761-773.

[9] Dasgupta A, Lim AR, Ghajar CM. Circulating and disseminated tumor cells: harbingers or initiators of metastasis? Mol Oncol 2017; 11(1): 40-61.

[10] Lin Y, Xu J, Lan H. Tumor-associated macrophages in tumor metastasis: biological roles and clinical therapeutic applications. J Hematol Oncol 2019; 12(1): 76.

[11] Hanahan D, Weinberg RA. Hallmarks of cancer: the next generation. Cell 2011; 144(5): 646-674.

[12] Hellmann MD, Li BT, Chaft JE, Kris MG. Chemotherapy remains an essential element of personalized care for persons with lung cancers. Ann Oncol Off J Eur Soc Med Oncol 2016; 27(10): 1829-1835.

[13] Wagner AD, Syn NL, Moehler M, Grothe W, Yong WP, Tai B-C, Ho J, Unverzagt S. Chemotherapy for advanced gastric cancer. Cochrane Database Syst Rev 2017; 8(8): CD004064-CD004064.

[14] Ventola CL. Cancer immunotherapy, Part 2: efficacy, safety, and other clinical considerations. P T 2017; 42(7): 452-463.

[15] Biersack B. Alkylating anticancer agents and their relations to MicroRNAs. Cancer Drug Resist. 2019; 2: 1-17.

[16] Berdis AJ. Inhibiting DNA polymerases as a therapeutic intervention against cancer. Front Mol Biosci 2017; 4: 78.
[17] Meegan MJ, O’Boyle NM. Special Issue "Anticancer Drugs". Pharmaceuticals (Basel) 2019; 12(3): 134.

[18] Bates D, Eastman A. Microtubule destabilising agents: far more than just antimitotic anticancer drugs. Br J Clin Pharmacol 2017; 83(2): 255-268.

[19] van Vuuren RJ, Visagie MH, Theron AE, Joubert AM. Antimitotic drugs in the treatment of cancer. Cancer Chemother Pharmacol 2015; 76(6): 1101-1112.

[20] Qi C, Wang X, Shen Z, Chen S, Yu H, Williams N, Wang G. Anti-mitotic chemotherapeutics promote apoptosis through TL1Aactivated death receptor 3 in cancer cells. Cell Res 2018; 28(5): 544555.

[21] Pistritto G, Trisciuoglio D, Ceci C, Garufi A, D’Orazi G. Apoptosis as anticancer mechanism: function and dysfunction of its modulators and targeted therapeutic strategies. Aging (Albany. NY) 2016; 8(4): 603-619.

[22] Bracci L, Schiavoni G, Sistigu A, Belardelli F. Immune-based mechanisms of cytotoxic chemotherapy: implications for the design of novel and rationale-based combined treatments against cancer. Cell Death Differ 2014; 21(1): 15-25.

[23] Rivera Vargas T, Apetoh L. Can immunogenic chemotherapies relieve cancer cell resistance to immune checkpoint inhibitors? Front Immunol 2019; 10: 1181.

[24] Zheng H-C. The molecular mechanisms of chemoresistance in cancers. Oncotarget 2017; 8(35): 59950-59964.

[25] Wang J, Seebacher N, Shi H, Kan Q, Duan Z. Novel strategies to prevent the development of multidrug resistance (MDR) in cancer. Oncotarget 2017; 8(48): 84559-84571.

[26] Zhang G-N, Ashby Jr CR, Zhang Y-K, Chen Z-S, Guo H. The reversal of antineoplastic drug resistance in cancer cells by $\beta$-elemene. Chin J Cancer 2015; 34(11): 488-495.

[27] Huang H, Aladelokun O, Ideta T, Giardina C, Ellis LM, Rosenberg DW. Inhibition of PGE2/EP4 receptor signaling enhances oxaliplatin efficacy in resistant colon cancer cells through modulation of oxidative stress. Sci Rep 2019; 9(1): 4954.

[28] Narayanan S, Cai C-Y, Assaraf YG, Guo H-Q, Cui Q, Wei L, Huang J-J, Ashby CR, Chen Z-S. Targeting the ubiquitin-proteasome pathway to overcome anti-cancer drug resistance. Drug Resist Updat 2020; 48: 100663.

[29] Gupta P, Xie M, Narayanan S, Wang Y-J, Wang X-Q, Yuan T, Wang Z, Yang D-H, Chen Z-S. GSK1904529A, a potent IGF-IR inhibitor, reverses MRP1-mediated multidrug resistance. J Cell Biochem 2017; 118(10): 3260-3267.

[30] De Vera AA, Gupta P, Lei Z, Liao D, Narayanan S, Teng Q, Reznik $\mathrm{SE}$, Chen Z-S. Immuno-oncology agent IPI-549 is a modulator of P-Glycoprotein (P-Gp, MDR1, ABCB1)-mediated multidrug resistance (MDR) in cancer: in vitro and in vivo. Cancer Lett 2019; 442: 91-103.

[31] Mansoori B, Mohammadi A, Davudian S, Shirjang S, Baradaran B. The different mechanisms of cancer drug resistance: a brief review. Adv Pharm Bull 2017; 7(3): 339-348.

[32] Nabholtz J-M, Slamon D. New adjuvant strategies for breast cancer: meeting the challenge of integrating chemotherapy and trastuzumab (herceptin). Semin Oncol 2001; 28: 1-12.

[33] Amé J-C, Spenlehauer C, de Murcia G. The PARP superfamily. BioEssays 2004; 26(8): 882-893.

[34] Vyas S, Chesarone-Cataldo M, Todorova T, Huang Y-H, Chang P. A systematic analysis of the PARP protein family identifies new functions critical for cell physiology. Nat Commun 2013; 4: 2240.

[35] Alemasova EE, Lavrik OI. Poly(ADP-Ribosyl)ation by PARP1: reaction mechanism and regulatory proteins. Nucleic Acids Res 2019; 47(8): 3811-3827.

[36] Bian C, Zhang C, Luo T, Vyas A, Chen S-H, Liu C, Kassab MA, Yang $\mathrm{Y}$, Kong M, Yu X. NADP+ is an endogenous PARP inhibitor in DNA damage response and tumor suppression. Nat Commun 2019; 10(1): 693.

[37] Gagné J-P, Isabelle M, Lo KS, Bourassa S, Hendzel MJ, Dawson VL, Dawson TM, Poirier GG. Proteome-wide identification of poly(ADP-Ribose) binding proteins and poly(ADP-Ribose)- 
associated protein complexes. Nucleic Acids Res 2008; 36(22): 69596976.

[38] Chambon P, Weill JD, Mandel P. Nicotinamide mononucleotide activation of a new DNA-dependent polyadenylic acid synthesizing nuclear enzyme. Biochem Biophys Res Commun 1963; 11(1): 39-43.

[39] Kraus WL. PARPs and ADP-ribosylation: 50 years ... and counting. Mol Cell 2015; 58(6): 902-910.

[40] Qin W, Wu H-J, Cao L-Q, Li H-J, He C-X, Zhao D, Xing L, Li P-Q, Jin X, Cao H-L. Research progress on PARP14 as a drug target. Front Pharmacol 2019; 10: 172.

[41] Ali AAE, Timinszky G, Arribas-Bosacoma R, Kozlowski M, Hassa PO, Hassler M, Ladurner AG, Pearl LH, Oliver AW. The zinc-finger domains of PARP1 cooperate to recognize dna strand breaks. Nat Struct Mol Biol 2012; 19(7): 685-692.

[42] Thomas C, Ji Y, Wu C, Datz H, Boyle C, MacLeod B, Patel S, Ampofo M, Currie M, Harbin J, Pechenkina K, Lodhi N, Johnson SJ, Tulin A V. Hit and run versus long-term activation of PARP-1 by its different domains fine-tunes nuclear processes. Proc Natl Acad Sci 2019; 116(20): 9941 LP - 9946.

[43] Daniels CM, Ong S-E, Leung AKL. The promise of proteomics for the study of ADP-ribosylation. Mol Cell 2015; 58(6): 911-924.

[44] Ray Chaudhuri A, Nussenzweig A. The multifaceted roles of PARP1 in DNA repair and chromatin remodelling. Nat Rev Mol Cell Biol 2017; 18(10): 610-621.

[45] Citarelli M, Teotia S, Lamb RS. Evolutionary history of the Poly(ADP-Ribose) polymerase gene family in eukaryotes. BMC Evol Biol 2010; 10: 308

[46] Feijs KLH, Forst AH, Verheugd P, Lüscher B. Macrodomaincontaining proteins: regulating new intracellular functions of mono(ADP-Ribosyl)ation. Nat Rev Mol Cell Biol 2013; 14(7): 443451.

[47] Lord CJ, Ashworth A. PARP Inhibitors: Synthetic lethality in the clinic. Science 2017; 355(6330): 1152-1158.

[48] Langelier M-F, Planck JL, Roy S, Pascal JM. Crystal structures of Poly(ADP-Ribose) Polymerase-1 (PARP-1) zinc fingers bound to DNA: structural and functional insights into DNA-dependent PARP1 activity. J Biol Chem 2011; 286(12): 10690-10701.

[49] Kamel D, Gray C, Kumar JSW, Kumar V. PARP inhibitor drugs in the treatment of breast, ovarian, prostate and pancreatic cancers: an update of clinical trials. Curr Drug Targets 2018; 19(1): 21-37.

[50] Virtanen V, Paunu K, Ahlskog JK, Varnai R, Sipeky C, Sundvall M. PARP inhibitors in prostate cancer-the preclinical rationale and current clinical development. Genes (Basel) 2019; 10(8).

[51] Hottiger MO, Hassa PO, Lüscher B, Schüler H, Koch-Nolte F. Toward a unified nomenclature for mammalian ADPRibosyltransferases. Trends Biochem Sci 2010; 35(4): 208-219.

[52] Palazzo L, Mikolčević P, Mikoč A, Ahel I. ADP-ribosylation signalling and human disease. Open Biol 2019; 9(4): 190041.

[53] Ratnam K, Low JA. Current development of clinical inhibitors of Poly(ADP-Ribose) polymerase in oncology. Clin Cancer Res 2007; 13(5): 1383 LP-1388.

[54] Carney B, Kossatz S, Lok BH, Schneeberger V, Gangangari KK, Pillarsetty NVK, Weber WA, Rudin CM, Poirier JT, Reiner T. Target engagement imaging of PARP inhibitors in small-cell lung cancer. Nat Commun 2018; 9(1): 176.

[55] Mashimo M, Kato J, Moss J. Structure and function of the arh family of ADP-ribosyl-acceptor hydrolases. DNA Repair (Amst) 2014; 23 : 88-94.

[56] Krietsch J, Rouleau M, Pic É, Ethier C, Dawson TM, Dawson VL, Masson J-Y, Poirier GG, Gagné J-P. Reprogramming cellular events by Poly(ADP-Ribose)-binding proteins. Mol Aspects Med 2013; 34(6): 1066-1087.

[57] Ke Y, Zhang J, Lv X, Zeng X, Ba X. Novel insights into parps in gene expression: regulation of RNA metabolism. Cell Mol Life Sci 2019; 76(17): 3283-3299.

[58] Gunderson CC, Moore KN. Olaparib: An oral PARP-1 and PARP2 inhibitor with promising activity in ovarian cancer. Futur Oncol 2015; 11(5): 747-757.

[59] Dockery LE, Gunderson CC, Moore KN. Rucaparib: the past, present, and future of a newly approved PARP inhibitor for ovarian cancer. Onco Targets Ther 2017; 10: 3029-3037.

[60] Scott L. Niraparib: first global approval. Drugs 2017; 77.

[61] Hoy S. Talazoparib: first global approval. Drugs 2018; 78.

[62] Abbotts R, Wilson 3rd DM. Coordination of DNA single strand break repair. free radic. Biol Med 2017; 107: 228-244.

[63] Kameshita I, Matsuda Z, Taniguchi T, Shizuta Y. Poly (ADP-ribose) synthetase. separation and identification of three proteolytic fragments as the substrate-binding domain, the DNA-binding domain, and the automodification domain. J Biol Chem 1984; 259(8): 47704776 .

[64] Thomas C, Tulin A V. Poly-ADP-Ribose polymerase: machinery for nuclear processes. Mol Aspects Med 2013; 34(6): 1124-1137.

[65] Eustermann S, Videler H, Yang J-C, Cole PT, Gruszka D, Veprintsev D, Neuhaus D. The DNA-binding domain of human PARP-1 interacts with DNA single-strand breaks as a monomer through its second zinc finger. J Mol Biol 2011; 407(1): 149-170.

[66] Decker P, Isenberg D, Muller S. Inhibition of Caspase-3-mediated poly(ADP-ribose) polymerase (PARP) apoptotic cleavage by human PARP autoantibodies and effect on cells undergoing apoptosis. $J$ Biol Chem 2000; 275(12): 9043-9046.

[67] Langelier M-F, Planck JL, Roy S, Pascal JM. Crystal structures of poly(ADP-ribose) polymerase-1 (PARP-1) zinc fingers bound to DNA. J Biol Chem 2011; 286(12): 10690-10701.

[68] Eustermann S, Brockmann C, Mehrotra PV, Yang J-C, Loakes D, West SC, Ahel I, Neuhaus D. Solution structures of the two PBZ domains from human APLF and their interaction with poly(ADPribose). Nat Struct Mol Biol 2010; 17(2): 241-243.

[69] Altmeyer M, Messner S, Hassa PO, Fey M, Hottiger MO. Molecular mechanism of poly(ADP-ribosyl)ation by PARP1 and identification of lysine residues as ADP-ribose acceptor sites. Nucleic Acids Res 2009; 37(11): 3723-3738.

[70] Riccio AA, Cingolani G, Pascal JM. PARP-2 Domain requirements for DNA damage-dependent activation and localization to sites of DNA damage. Nucleic Acids Res 2016; 44(4): 1691-1702.

[71] Liu C, Vyas A, Kassab MA, Singh AK, Yu X. The role of poly ADP-ribosylation in the first wave of DNA damage response. $\mathrm{Nu}$ cleic Acids Res 2017; 45(14): 8129-8141.

[72] Schreiber V, Dantzer F, Ame J-C, de Murcia G. Poly(ADP-ribose): novel functions for an old molecule. Nat Rev Mol Cell Biol 2006 7(7): 517-528.

[73] Morales J, Li L, Fattah FJ, Dong Y, Bey EA, Patel M, Gao J, Boothman DA. Review of poly (ADP-ribose) polymerase (PARP) mechanisms of action and rationale for targeting in cancer and other diseases. Crit Rev Eukaryot Gene Expr 2014; 24(1): 15-28.

[74] Wang L, Liang C, Li F, Guan D, Wu X, Fu X, Lu A, Zhang G. PARP1 in carcinomas and PARP1 inhibitors as antineoplastic drugs. Int J Mol Sci 2017; 18(10): 2111.

[75] Brown JS, O'Carrigan B, Jackson SP, Yap TA. Targeting DNA repair in cancer: beyond PARP inhibitors. Cancer Discov 2017; 7(1): 20 37.

[76] Broustas CG, Lieberman HB. DNA damage response genes and the development of cancer metastasis. Radiat Res 2014; 181(2): 111130.

[77] De Vos M, Schreiber V, Dantzer F. The diverse roles and clinical relevance of PARPs in DNA Damage Repair: current state of the art. Biochem Pharmacol 2012; 84(2): 137-146.

[78] Calabrese CR, Almassy R, Barton S, Batey MA, Calvert AH, CananKoch S, Durkacz BW, Hostomsky Z, Kumpf RA, Kyle S, Li J, Maegley K, Newell DR, Notarianni E, Stratford IJ, Skalitzky D, Thomas HD, Wang L-Z, Webber SE, Williams KJ, Curtin NJ. Anticancer chemosensitization and radiosensitization by the novel poly(ADPRibose) polymerase-1 inhibitor AG14361. J Natl Cancer Inst 2004; 96(1): 56-67.

[79] Ledermann J, Harter P, Gourley C, Friedlander M, Vergote I, Rustin G, Scott CL, Meier W, Shapira-Frommer R, Safra T, Matei D, Fielding A, Spencer S, Dougherty B, Orr M, Hodgson D, Barrett JC, Matulonis U. Olaparib maintenance therapy in patients with platinumsensitive relapsed serous ovarian cancer: a preplanned retrospective 
analysis of outcomes by BRCA status in a randomised phase 2 trial. Lancet Oncol 2014; 15(8): 852-861.

[80] Shaughnessy J. O'. Iniparib plus chemotherapy in metastatic triplenegative breast cancer. N Engl J Med 2011; 364: 205-214.

[81] Burd R. The selective PARP inhibitor, CEP-9722, exhibits significant radiosensitization against radioresistant U87 human glioblastoma xenografts and does not potentiate radiation-induced normal tissue toxicity. Cancer Res 2008; 68: 4214.

[82] Curtin NJ, Wang L-Z, Yiakouvaki A, Kyle S, Arris CA, Canan-Koch S, Webber SE, Durkacz BW, Calvert HA, Hostomsky Z, Newell DR. Novel poly(ADP-ribose) polymerase-1 inhibitor, AG14361, restores sensitivity to temozolomide in mismatch repair-deficient cells. Clin Cancer Res 2004; 10(3): 881-889.

[83] Kummar S, Chen A, Ji J, Zhang Y, Reid JM, Ames M, Jia L, Weil M, Speranza G, Murgo AJ, Kinders R, Wang L, Parchment RE, Carter J, Stotler H, Rubinstein L, Hollingshead M, Melillo G, Pommier Y, Bonner W, Tomaszewski JE, Doroshow JH. Phase I study of PARP inhibitor ABT-888 in combination with topotecan in adults with refractory solid tumors and lymphomas. Cancer Res 2011; 71(17): 5626-5634

[84] Bryant HE, Schultz N, Thomas HD, Parker KM, Flower D, Lopez E Kyle S, Meuth M, Curtin NJ, Helleday T. Specific killing of BRCA2deficient tumours with inhibitors of poly(ADP-ribose) polymerase. Nature 2005; 434(7035): 913-917.

[85] Farmer H, McCabe N, Lord CJ, Tutt ANJ, Johnson DA, Richardson TB, Santarosa M, Dillon KJ, Hickson I, Knights C, Martin NMB, Jackson SP, Smith GCM, Ashworth A. Targeting the DNA repair defect in BRCA mutant cells as a therapeutic strategy. Nature 2005; 434(7035): 917-921.

[86] Kennedy RD, D'Andrea AD. DNA repair pathways in clinical practice: lessons from pediatric cancer susceptibility syndromes. J Clin Oncol 2006; 24(23): 3799-3808.

[87] Bunting SF, Callén E, Wong N, Chen H-T, Polato F, Gunn A, Bothmer A, Feldhahn N, Fernandez-Capetillo O, Cao L, Xu X, Deng C-X, Finkel T, Nussenzweig M, Stark JM, Nussenzweig A. 53BP1 inhibits homologous recombination in Brcal-deficient cells by blocking resection of DNA breaks. Cell 2010; 141(2): 243-254

[88] Patel AG, Sarkaria JN, Kaufmann SH. Nonhomologous end joining drives poly(ADP-ribose) polymerase (PARP) inhibitor lethality in homologous recombination-deficient cells. Proc Natl Acad Sci USA 2011; 108(8): 3406-3411.

[89] Javle M, Curtin NJ. The role of PARP in DNA repair and its therapeutic exploitation. Br J Cancer 2011; 105(8): 1114-1122.

[90] Welcsh PL, King M-C. BRCA1 and BRCA2 and the genetics of breast and ovarian cancer. Hum Mol Genet 2001; 10(7): 705-713.

[91] Drew Y, Mulligan EA, Vong W-T, Thomas HD, Kahn S, Kyle S, Mukhopadhyay A, Los G, Hostomsky Z, Plummer ER, Edmondson RJ, Curtin NJ. Therapeutic potential of poly(ADP-ribose) polymerase inhibitor AG014699 in human cancers with mutated or methylated BRCA1 or BRCA2. JNCI J Natl Cancer Inst 2010; 103(4): 334-346.

[92] Cousineau I, Belmaaza A. EMSY overexpression disrupts the BRCA2/RAD51 pathway in the DNA-damage response: implications for chromosomal instability/recombination syndromes as checkpoint diseases. Mol Genet Genomics 2011; 285(4): 325-340.

[93] Milella M, Falcone I, Conciatori F, Cesta Incani U, Del Curatolo A, Inzerilli N, Nuzzo CMA, Vaccaro V, Vari S, Cognetti F, Ciuffreda L. PTEN: multiple functions in human malignant tumors. Front. Oncol. 2015; 5: 24.

[94] Mendes-Pereira AM, Martin SA, Brough R, McCarthy A, Taylor JR, Kim J-S, Waldman T, Lord CJ, Ashworth A. Synthetic lethal targeting of pten mutant cells with PARP inhibitors. EMBO Mol Med 2009; 1(6-7): 315-322

[95] Feng L, Achanta G, Pelicano H, Zhang W, Plunkett W, Huang P. Role of P53 in cellular response to anticancer nucleoside analog-induced DNA damage. Int J Mol Med 2000; 5: 597-604.

[96] Awada A, Campone M, Varga A, Aftimos P, Frenel J-S, Bahleda R, Gombos A, Bourbouloux E, Soria J-C. An open-label, doseescalation study to evaluate the safety and pharmacokinetics of CEP-
9722 (a PARP-1 and PARP-2 inhibitor) in combination with gemcitabine and cisplatin in patients with advanced solid tumors. Anticancer Drugs 2016; 27(4): 342-348.

[97] Dasari S, Tchounwou PB. Cisplatin in cancer therapy: molecular mechanisms of action. Eur J Pharmacol 2014; 740: 364-378.

[98] Xiufeng Z, Haijun Z, Silei B, Manman D, Yong Z, Lian Y, Zhihong F, Bing X. Co-operation of ABT-199 and gemcitabine in impeding DNA damage repair and inducing cell apoptosis for synergistic therapy of T-Cell acute lymphoblastic leukemia. Anticancer Drugs 2019 30(2): 138-148.

[99] Parvathaneni S, Sharma S. The DNA repair helicase RECQ1 has a checkpoint-dependent role in mediating DNA damage responses induced by gemcitabine. J Biol Chem 2019; 294(42): 15330-15345.

[100] Galluzzi L, Senovilla L, Vitale I, Michels J, Martins I, Kepp O, Castedo M, Kroemer G. Molecular mechanisms of cisplatin resistance. Oncogene 2012; 31(15): 1869-1883.

[101] Rottenberg S, Jaspers JE, Kersbergen A, van der Burg E, Nygren $\mathrm{AOH}$, Zander SAL, Derksen PWB, de Bruin M, Zevenhoven J, Lau A, Boulter R, Cranston A, Connor MJ, Martin NMB, Borst P, Jonkers J. High sensitivity of BRCA1-deficient mammary tumors to the PARP inhibitor AZD2281 alone and in combination with platinum drugs. Proc. Natl Acad Sci 2008; 105(44): 17079-17084.

[102] Donawho CK, Luo Y, Luo Y, Penning TD, Bauch JL, Bouska JJ, Bontcheva-Diaz VD, Cox BF, DeWeese TL, Dillehay LE, Ferguson DC, Ghoreishi-Haack NS, Grimm DR, Guan R, Han EK, HolleyShanks RR, Hristov B, Idler KB, Jarvis K, Johnson EF, Kleinberg LR, Klinghofer V, Lasko LM, Liu X, Marsh KC, McGonigal TP, Meulbroek JA, Olson AM, Palma JP, Rodriguez LE, Shi Y, Stavropoulos JA, Tsurutani AC, Zhu G-D, Rosenberg SH, Giranda VL, Frost DJ. ABT-888, an orally active poly(ADP-Ribose) polymerase inhibitor that potentiates DNA-damaging agents in preclinical tumor models. Clin Cancer Res 2007; 13(9): 2728-2737.

[103] Tentori L, Graziani G. Chemopotentiation by parp inhibitors in cancer therapy. Pharmacol Res 2005; 52(1): 25-33.

[104] Fleury H, Carmona E, Morin VG, Meunier L, Masson J-Y, Tonin PN, Provencher D, Mes-Masson A-M. Cumulative defects in DNA repair pathways drive the PARP inhibitor response in high-grade serous epithelial ovarian cancer cell lines. Oncotarget 2017; 8(25): 40152 40168.

[105] Wang B, Chu D, Feng Y, Shen Y, Aoyagi-Scharber M, Post LE. Discovery and characterization of (8s,9r)-5-fluoro-8 (4-fluorophenyl)-9-(1-methyl-1h-1,2,4-triazol-5-yl)-2,7,8,9tetrahydro-3h-pyrido[4,3,2-de]phthalazin-3-one (BMN 673, Talazoparib), a novel, highly potent, and orally efficacious poly(ADP-ribose) polymer. J Med Chem 2016; 59(1): 335-357.

[106] Hoy SM. Talazoparib: first global approval. Drugs 2018; 78(18): 1939-1946.

[107] Litton JK, Scoggins M, Ramirez DL, Murthy RK, Whitman GJ, Hess KR, Adrada BE, Moulder SL, Barcenas CH, Valero V, Gomez JS, Mittendorf EA, Thompson A, Helgason T, Mills GB, PiwnicaWorms H, Arun BK. A feasibility study of neoadjuvant talazoparib for operable breast cancer patients with a germline BRCA mutation demonstrates marked activity. NPJ Breast Cancer 2017; 3: 49.

[108] Poggio F, Bruzzone M, Ceppi M, Conte B, Martel S, Maurer C, Tagliamento M, Viglietti G, Del Mastro L, de Azambuja E, Lambertini M. Single-agent PARP inhibitors for the treatment of patients with BRCA-mutated HER2-negative metastatic breast cancer: a systematic review and meta-analysis. ESMO Open 2018; 3(4): e000361.

[109] Jain PG, Patel BD. Medicinal chemistry approaches of Poly ADPribose Polymerase 1 (PARP1) inhibitors as anticancer agents-a recent update. Eur J Med Chem 2019; 165: 198-215.

[110] Passeri D, Camaioni E, Liscio P, Sabbatini P, Ferri M, Carotti A, Giacchè N, Pellicciari R, Gioiello A, Macchiarulo A. Concepts and molecular aspects in the polypharmacology of PARP-1 inhibitors. ChemMedChem 2016; 11(12): 1219-1226.

[11] Murai J, Huang S-YN, Renaud A, Zhang Y, Ji J, Takeda S, Morris J, Teicher B, Doroshow JH, Pommier Y. Stereospecific PARP trapping by BMN 673 and comparison with olaparib and rucaparib. $\mathrm{Mo}$ Cancer Ther 2014; 13(2): 433-443. 
[112] Engert F, Kovac M, Baumhoer D, Nathrath M, Fulda S. Osteosarcoma cells with genetic signatures of BRCAness are susceptible to the PARP inhibitor talazoparib alone or in combination with chemotherapeutics. Oncotarget 2017; 8(30): 48794-48806.

[113] Litton JK, Rugo HS, Ettl J, Hurvitz SA, Gonçalves A, Lee K-H, Fehrenbacher L, Yerushalmi R, Mina LA, Martin M. Talazoparib in patients with advanced breast cancer and a germline BRCA mutation. N Engl J Med 2018; 379(8): 753-763.

[114] Turner NC, Telli ML, Rugo HS, Mailliez A, Ettl J, Grischke EM, Mina LA, Balmana J, Fasching PA, Hurvitz SA, Wardley AM, Chappey C, Hannah AL, Robson ME. A phase II study of talazoparib after platinum or cytotoxic nonplatinum regimens in patients with advanced breast cancer and germline BRCA1/2 mutations (ABRAZO). Clin Cancer Res 2019; 25(9): 2717-2724.

[115] Thorsell AG, Ekblad T, Karlberg T, Low M, Pinto AF, Tresaugues L, Moche M, Cohen MS, Schuler H. Structural Basis for Potency and Promiscuity in Poly(ADP-Ribose) Polymerase (PARP) and Tankyrase Inhibitors. J Med Chem 2017; 60(4): 1262-1271.

[116] Beck C, Boehler C, Guirouilh Barbat J, Bonnet ME, Illuzzi G, Ronde P, Gauthier LR, Magroun N, Rajendran A, Lopez BS, Scully R, Boussin FD, Schreiber V, Dantzer F. PARP3 affects the relative contribution of homologous recombination and nonhomologous endjoining pathways. Nucleic Acids Res 2014; 42(9): 5616-5632.

[117] de Bono J, Ramanathan RK, Mina L, Chugh R, Glaspy J, Rafii S, Kaye S, Sachdev J, Heymach J, Smith DC, Henshaw JW, Herriott A, Patterson M, Curtin NJ, Byers LA, Wainberg ZA. Phase I, doseescalation, two-part trial of the PARP inhibitor talazoparib in patients with advanced germline BRCA1/2 mutations and selected sporadic cancers. Cancer Discov 2017; 7(6): 620-629.

[118] Shen Y, Rehman FL, Feng Y, Boshuizen J, Bajrami I, Elliott R, Wang B, Lord CJ, Post LE, Ashworth A. BMN 673, a novel and highly potent PARP1/2 inhibitor for the treatment of human cancers with DNA repair deficiency. Clin Cancer Res 2013; 19(18): 5003-5015.

[119] Yu Y, Durairaj C, Shi H, Wang DD. Population pharmacokinetics of talazoparib in patients with advanced cancer. J Clin Pharmacol 2020; 60(2): 218-228.

[120] Exman P, Barroso-Sousa R, Tolaney SM. Evidence to date: talazoparib in the treatment of breast cancer. Onco Targets Ther 2019; 12: $5177-5187$.

[121] McCann KE, Hurvitz SA. Advances in the use of PARP inhibitor therapy for breast cancer. Drugs Context 2018; 7: 212540.

[122] Lesueur P, Chevalier F, El-Habr EA, Junier MP, Chneiweiss H, Castera L, Muller E, Stefan D, Saintigny Y. Radiosensitization effect of talazoparib, a PARP inhibitor, on glioblastoma stem cells exposed to low and high linear energy transfer radiation. Sci Rep 2018; 8(1): 3664.

[123] Berek JS, Matulonis UA, Peen U, Ghatage P, Mahner S, Redondo A, Lesoin A, Colombo N, Vergote I, Rosengarten O. Safety and dose modification for patients receiving niraparib. Ann Oncol 2018; 29(8): 1784-1792.

[124] Ison G, Howie LJ, Amiri-Kordestani L, Zhang L, Tang S, Sridhara R, Pierre V, Charlab R, Ramamoorthy A, Song P, Li F, Yu J, Manheng W, Palmby TR, Ghosh S, Horne HN, Lee EY, Philip R, Dave K, Chen XH, Kelly SL, Janoria KG, Banerjee A, Eradiri O, Dinin J, Goldberg KB, Pierce WF, Ibrahim A, Kluetz PG, Blumenthal GM, Beaver JA, Pazdur R. FDA approval summary: niraparib for the maintenance treatment of patients with recurrent ovarian cancer in response to platinum-based chemotherapy. Clin Cancer Res 2018; 24(17): 40664071.

[125] Jones P, Altamura S, Boueres J, Ferrigno F, Fonsi M, Giomini C, Lamartina S, Monteagudo E, Ontoria JM, Orsale MV. Discovery of 2-4-[(3s)-piperidin-3-yl] phenyl-2h-indazole-7-carboxamide (MK-4827): a novel oral poly (ADP-ribose) polymerase (PARP) inhibitor efficacious in BRCA-1 and-2 mutant tumors. $J$ Med Chem 2009; 52(22): 7170-7185.

[126] Bridges KA, Toniatti C, Buser CA, Liu H, Buchholz TA, Meyn RE. Niraparib (MK-4827), a novel poly(ADP-ribose) polymerase inhibitor, radiosensitizes human lung and breast cancer cells. Oncotarget 2014; 5(13): 5076-5086.
[127] Wang L, Mason KA, Ang KK, Buchholz T, Valdecanas D, Mathu A, Buser-Doepner C, Toniatti C, Milas L. MK-4827, a PARP-1/-2 inhibitor, strongly enhances response of human lung and breast cancer xenografts to radiation. Invest New Drugs 2012; 30(6): 2113-2120.

[128] Sandhu SK, Schelman WR, Wilding G, Moreno V, Baird RD, Miranda S, Hylands L, Riisnaes R, Forster M, Omlin A, Kreischer N, Thway K, Gevensleben H, Sun L, Loughney J, Chatterjee M, Toniatti C, Carpenter CL, Iannone R, Kaye SB, de Bono JS, Wenham RM. The poly(ADP-Ribose) polymerase inhibitor niraparib (MK4827) in BRCA mutation carriers and patients with sporadic cancer: a phase 1 dose-escalation trial. Lancet Oncol 2013; 14(9): 882-892.

[129] Sisay M, Edessa D. PARP inhibitors as potential therapeutic agents for various cancers: focus on niraparib and its first global approval for maintenance therapy of gynecologic cancers. Gynecol Oncol Res Pract 2017; 4: 18.

[130] van Andel L, Zhang Z, Lu S, Kansra V, Agarwal S, Hughes L, Tibben MM, Gebretensae A, Lucas L, Hillebrand MJX. Human mass balance study and metabolite profiling of $14 \mathrm{C}$-Niraparib, a novel poly (ADPribose) polymerase (PARP)-1 and PARP-2 inhibitor, in patients with advanced cancer. Invest. New Drugs 2017; 35(6): 751-765.

[131] Zhang Z, Kansra V, Andel L, Tibben M, Rosing H, Lu S, Agarwal S, Hughes L, Schellens JY, Beijnen JH. Characterization of absorption, metabolism, and elimination of niraparib, an investigational poly (ADP-ribose) polymerase inhibitor, in cancer patients. Clin Ther 2017; 39: e7-e8.

[132] Sun K, Mikule K, Wang Z, Poon G, Vaidyanathan A, Smith G, Zhang ZY, Hanke J, Ramaswamy S, Wang J. A comparative pharmacokinetic study of PARP inhibitors demonstrates favorable properties for Niraparib efficacy in preclinical tumor models. Oncotarget 2018; 9(98): 37080-37096

[133] van Andel L, Rosing H, Zhang Z, Hughes L, Kansra V, Sanghvi M, Tibben MM, Gebretensae A, Schellens JHM, Beijnen JH. Determination of the absolute oral bioavailability of niraparib by simultaneous administration of a (14)C-Microtracer and therapeutic dose in cancer patients. Cancer Chemother Pharmacol 2018; 81(1): 39-46.

[134] Sun K, Mikule K, Wang Z, Poon G, Vaidyanathan A, Smith G, Zhang Z-Y, Hanke J, Ramaswamy S, Wang J. A comparative pharmacokinetic study of PARP inhibitors demonstrates favorable properties for Niraparib efficacy in preclinical tumor models. Oncotarget 2018; 9(98): 37080-37096

[135] González-Martín A, Pothuri B, Vergote I, DePont Christensen R, Graybill W, Mirza MR, McCormick C, Lorusso D, Hoskins P, Freye G. Niraparib in patients with newly diagnosed advanced ovarian cancer. N Engl J Med 2019

[136] Genther Williams SM, Kuznicki AM, Andrade P, Dolinski BM, Elbi C, O'Hagan RC, Toniatti C. Treatment with the PARP inhibitor, niraparib, sensitizes colorectal cancer cell lines to irinotecan regardless of MSI/MSS status. Cancer Cell Int 2015; 15(1): 14.

[137] Deas O, Cairo S, Wilcoxen K, Mikule K, Tran T-A, Timms K, Judde J-G. Abstract 4353: preclinical evaluation of the PARP inhibitor Niraparib and cytotoxic chemotherapy alone or in combination in a panel of 25 triple-negative breast cancer PDX models: relevance of BRCA mutations, HRD status and other Biomarkers. Cancer Res 2016; 76(14 Supplement): 4353.

[138] AlHilli MM, Becker MA, Weroha SJ, Flatten KS, Hurley RM, Harrell MI, Oberg AL, Maurer MJ, Hawthorne KM, Hou X, Harrington SC, McKinstry S, Meng XW, Wilcoxen KM, Kalli KR, Swisher EM, Kaufmann SH, Haluska P. In vivo anti-tumor activity of the PARP inhibitor Niraparib in homologous recombination deficient and proficient ovarian carcinoma. Gynecol Oncol 2016; 143(2): 379-388.

[139] Mirza MR, Monk BJ, Herrstedt J, Oza AM, Mahner S, Redondo A, Fabbro M, Ledermann JA, Lorusso D, Vergote I. Niraparib maintenance therapy in platinum-sensitive, recurrent ovarian cancer. $N E n g l$ J Med 2016; 375(22): 2154-2164.

[140] Christ TN. Olaparib: a tale of two dosage forms. Semin Oncol 2019; 46(1): 100-101.

[141] Deeks ED. Olaparib: first global approval. Drugs 2015; 75(2): 231240.

[142] Thorsell A-G, Ekblad T, Karlberg T, Löw M, Pinto AF, Trésaugues 
L, Moche M, Cohen MS, Schüler H. Structural basis for potency and promiscuity in poly(ADP-Ribose) polymerase (PARP) and tankyrase inhibitors. J Med Chem 2017; 60(4): 1262-1271.

[143] Friedlander M, Gebski V, Gibbs E, Davies L, Bloomfield R, Hilpert F, Wenzel LB, Eek D, Rodrigues M, Clamp A, Penson RT, Provencher D, Korach J, Huzarski T, Vidal L, Salutari V, Scott C, Nicoletto MO, Tamura K, Espinoza D, Joly F, PujadeLauraine E. Health-related quality of life and patient-centred outcomes with olaparib maintenance after chemotherapy in patients with platinum-sensitive, relapsed ovarian cancer and a BRCA $1 / 2$ mutation (SOLO2/ENGOT Ov-21): a placebo-controlled, phase 3 randomised tria. Lancet Oncol 2018; 19(8): 1126-1134.

[144] Astrazeneca. AstraZeneca Pharmaceuticals LP. LynparzaTM (Olaparib) Capsules,for Oral Use: US Prescribing Information. 2014. Accessed 52015. http://www.Accessdata.Fda.Gov/Scripts/Cder/Drugsatfda/Index. Cfm 2014.

[145] Clarkson-Jones J, Page C, Sarda S, Swaisland H. 417 Human biotransformation of olaparib (AZD2281) an oral poly (ADP-ribose) polymerase (PARP) inhibitor. Ejc Suppl 2010; 7(8): 132.

[146] Rolfo C, de Vos-Geelen J, Isambert N, Molife LR, Schellens JHM, De Grève J, Dirix L, Grundtvig-Sørensen P, Jerusalem G, Leunen K. Pharmacokinetics and safety of olaparib in patients with advanced solid tumours and renal impairment. Clin Pharmacokinet 2019: 110.

[147] Ledermann JA, Pujade-Lauraine E. Olaparib as maintenance treatment for patients with platinum-sensitive relapsed ovarian cancer. Ther Adv Med Oncol 2019; 11: 1758835919849753.

[148] Pujade-Lauraine E, Ledermann JA, Selle F, Gebski V, Penson RT, Oza AM, Korach J, Huzarski T, Poveda A, Pignata S. Olaparib tablets as maintenance therapy in patients with platinum-sensitive, relapsed ovarian cancer and a BRCA1/2 mutation (SOLO2/ENGOT-Ov21): a double-blind, randomised, placebo-controlled, phase 3 trial. Lancet Oncol 2017; 18(9): 1274-1284.

[149] Washington CR, Richardson DL, Moore KN. Olaparib in the treatment of ovarian cancer. Future Oncol 2019; 15(30): 3435-3449.

[150] Evers B, Drost R, Schut E, de Bruin M, van der Burg E, Derksen PWB, Holstege H, Liu X, van Drunen E, Beverloo HB, Smith GCM, Martin NMB, Lau A, O'Connor MJ, Jonkers J. Selective inhibition of BRCA2-deficient mammary tumor cell growth by AZD2281 and cisplatin. Clin Cancer Res 2008; 14(12): 3916-3925.

[151] Hay T, Matthews JR, Pietzka L, Lau A, Cranston A, Nygren AOH, Douglas-Jones A, Smith GCM, Martin NMB, O’Connor M, Clarke AR. Poly(ADP-ribose) polymerase-1 inhibitor treatment regresses autochthonous Brca2/P53-mutant mammary tumors in vivo and delays tumor relapse in combination with carboplatin. Cancer Res 2009; 69(9): 3850-3855.

[152] Audeh MW, Carmichael J, Penson RT, Friedlander M, Powell B, Bell-McGuinn KM, Scott C, Weitzel JN, Oaknin A, Loman N, Lu K, Schmutzler RK, Matulonis U, Wickens M, Tutt A. Oral poly(ADPribose) polymerase inhibitor olaparib in patients with BRCA1 or BRCA2 mutations and recurrent ovarian cancer: a proof-of-concept trial. Lancet 2010; 376(9737): 245-251.

[153] Pujade-Lauraine E, Ledermann JA, Selle F, Gebski V, Penson RT, Oza AM, Korach J, Huzarski T, Poveda A, Pignata S, Friedlander M, Colombo N, Harter P, Fujiwara K, Ray-Coquard I, Banerjee S, Liu J, Lowe ES, Bloomfield R, Pautier P. Olaparib tablets as maintenance therapy in patients with platinum-sensitive, relapsed ovarian cancer and a BRCA1/2 mutation (SOLO2/ENGOT-Ov21): a double-blind, randomised, placebo-controlled, phase 3 trial. Lancet Oncol 2017; 18(9): 1274-1284.

[154] Mateo J, Carreira S, Sandhu S, Miranda S, Mossop H, Perez-Lopez R, Nava Rodrigues D, Robinson D, Omlin A, Tunariu N. DNA-repair defects and olaparib in metastatic prostate cancer. $N$ Engl $J$ Med 2015; 373(18): 1697-1708.

[155] Golan T, Hammel P, Reni M, Van Cutsem E, Macarulla T, Hall MJ, Park JO, Hochhauser D, Arnold D, Oh DY. Maintenance olaparib for germline BRCA-mutated metastatic pancreatic cancer. $N$ Engl J Med 2019; 381(4):317-327.
[156] Drapkin BJ, George J, Christensen CL, Mino-Kenudson M, Dries R Sundaresan T, Phat S, Myers DT, Zhong J, Igo P. Genomic and functional fidelity of small cell lung cancer patient-derived xenografts. Cancer Discov 2018; 8(5): 600-615.

[157] Farago AF, Yeap BY, Stanzione M, Hung YP, Heist RS, Marcoux JP, Zhong J, Rangachari D, Barbie DA, Phat S, Myers DT, Morris R, Kem M, Dubash TD, Kennedy EA, Digumarthy SR, Sequist L V, Hata AN, Maheswaran S, Haber DA, Lawrence MS, Shaw AT, Mino-Kenudson M, Dyson NJ, Drapkin BJ. Combination olaparib and temozolomide in relapsed small-cell lung cancer. Cancer Discov 2019; 9(10): 1372-1387.

[158] Robson M, Im S-A, Senkus E, Xu B, Domchek SM, Masuda N, Delaloge S, Li W, Tung N, Armstrong A, Wu W, Goessl C, Runswick $\mathrm{S}$, Conte P. Olaparib for metastatic breast cancer in patients with a germline BRCA mutation. N Engl J Med 2017; 377(6): 523-533.

[159] Min R, Wu W, Wang M, Tang L, Chen D, Zhao H, Zhang C, Jiang Y. Discovery of 2-(1-(3-(4-chloroxyphenyl)-3-oxo- propyl)pyrrolidine3-yl)-1h-benzo[d]imidazole-4-carboxamide: a potent poly(ADPribose) polymerase (PARP) inhibitor for treatment of cancer. Molecules 2019; 24(10): 1901.

[160] Owonikoko TK, Zhang G, Deng X, Rossi MR, Switchenko JM, Doho GH, Chen Z, Kim S, Strychor S, Christner SM, Beumer J, Li C, Yue P, Chen A, Sica GL, Ramalingam SS, Kowalski J, Khuri FR, Sun S-Y. Poly (ADP) ribose polymerase enzyme inhibitor, veliparib, potentiates chemotherapy and radiation in vitro and in vivo in small cell lung cancer. Cancer Med 2014; 3(6): 1579-1594.

[161] Albert JM, Cao C, Kim KW, Willey CD, Geng L, Xiao D, Wang H, Sandler A, Johnson DH, Colevas AD, Low J, Rothenberg ML, Lu B. Inhibition of poly(ADP-ribose) polymerase enhances cell death and improves tumor growth delay in irradiated lung cancer models. Clin Cancer Res 2007; 13(10): 3033-3042.

[162] Gupta SK, Mladek AC, Carlson BL, Boakye-Agyeman F, Bakken KK, Kizilbash SH, Schroeder MA, Reid J, Sarkaria JN. Discordant in vitro and in vivo chemopotentiating effects of the PARP inhibitor veliparib in temozolomide-sensitive versus -resistant glioblastoma multiforme xenografts. Clin Cancer Res 2014; 20(14): 3730-3741.

[163] Kummar S, Ji J, Morgan R, Lenz H-J, Puhalla SL, Belani CP, Gandara DR, Allen D, Kiesel B, Beumer JH, Newman EM, Rubinstein L, Chen A, Zhang Y, Wang L, Kinders RJ, Parchment RE, Tomaszewski JE, Doroshow JH. A phase i study of veliparib in combination with metronomic cyclophosphamide in adults with refractory solid tumors and lymphomas. Clin Cancer Res 2012; 18(6): 1726-1734.

[164] Kummar S, Oza AM, Fleming GF, Sullivan DM, Gandara DR, Naughton MJ, Villalona-Calero MA, Morgan RJ, Szabo PM, Youn A, Chen AP, Ji J, Allen DE, Lih C-J, Mehaffey MG, Walsh WD, McGregor PM, Steinberg SM, Williams PM, Kinders RJ, Conley BA, Simon RM, Doroshow JH. Randomized trial of oral cyclophosphamide and veliparib in high-grade serous ovarian, primary peritoneal, or fallopian tube cancers, or BRCA-mutant ovarian cancer. Clin. Cancer Res 2015; 21(7): 1574-1582.

[165] Jenner ZB, Sood AK, Coleman RL. Evaluation of rucaparib and companion diagnostics in the PARP inhibitor landscape for recurrent ovarian cancer therapy. Future Oncol. 2016; 12(12): 1439-1456.

[166] Canan S, Maegley K, Curtin NJ. Strategies employed for the development of PARP inhibitors. Methods Mol Biol 2017; 1608: 271-297.

[167] Robillard L, Nguyen M, Harding TC, Simmons AD. Abstract 2475: in vitro and in vivo assessment of the mechanism of action of the PARP inhibitor rucapar. Cancer Res 2017; 77: 2475-2475.

[168] Syed YY. Rucaparib: First global approval. Drugs 2017; 77(5): 585592.

[169] Swisher EM, Lin KK, Oza AM, Scott CL, Giordano H, Sun J, Konecny GE, Coleman RL, Tinker AV, O'Malley DM, Kristeleit RS, Ma L, Bell-McGuinn KM, Brenton JD, Cragun JM, Oaknin A, RayCoquard I, Harrell MI, Mann E, Kaufmann SH, Floquet A, Leary A, Harding TC, Goble S, Maloney L, Isaacson J, Allen AR, Rolfe L, Yelensky R, Raponi M, McNeish IA. Rucaparib in relapsed, platinumsensitive high-grade ovarian carcinoma (ARIEL2 part 1): an international, multicentre, open-label, phase 2 trial. Lancet Oncol 2017; 18(1): 75-87. 
[170] Coleman RL, Oza AM, Lorusso D, Aghajanian C, Oaknin A, Dean A, Colombo N, Weberpals JI, Clamp A, Scambia G, Leary A, Holloway RW, Gancedo MA, Fong PC, Goh JC, O'Malley DM, Armstrong DK, Garcia-Donas J, Swisher EM, Floquet A, Konecny GE, McNeish IA, Scott CL, Cameron T, Maloney L, Isaacson J, Goble S, Grace C, Harding TC, Raponi M, Sun J, Lin KK, Giordano H, Ledermann JA, investigators A. Rucaparib maintenance treatment for recurrent ovarian carcinoma after response to platinum therapy (ARIEL3): a randomised, double-blind, placebo-controlled, phase 3 trial. Lancet 2017; 390(10106): 1949-1961.

[171] Plummer R, Lorigan P, Steven N, Scott L, Middleton MR, Wilson RH, Mulligan E, Curtin N, Wang D, Dewji R, Abbattista A, Gallo J, Calvert H. A phase II study of the potent PARP inhibitor, rucaparib (PF-01367338, AG014699), with temozolomide in patients with metastatic melanoma demonstrating evidence of chemopotentiation. Cancer chemother. Pharmacol 2013; 71(5): 1191-1199.

[172] Miknyoczki S. The selective poly(ADP-Ribose) PolymeraseInhibitor, CEP-8983, increases the sensitivity of chemoresistant tumor cells to temozolomide and irinotecan but does not potentiate myelotoxicity. Mol Cancer Ther 2007; 6(8): 2290-302.

[173] Kurnit KC, Coleman RL, Westin SN. Using PARP inhibitors in the treatment of patients with ovarian cancer. Curr Treat Options Oncol 2018; 19(12): 1 .

[174] Plummer R, Stephens P, Aissat-Daudigny L, Cambois A, Moachon G, Brown PD, Campone M. Phase 1 dose-escalation study of the PARP inhibitor CEP-9722 as monotherapy or in combination with temozolomide in patients with solid tumors. Cancer Chemother Pharmacol 2014; 74(2): 257-265.

[175] Tentori L, Portarena I, Torino F, Scerrati M, Navarra P, Graziani G. Poly(ADP-ribose) polymerase inhibitor increases growth inhibition and reduces $\mathrm{G}(2) / \mathrm{M}$ cell accumulation induced by temozolomide in malignant glioma cells. Glia 2002; 40(1): 44-54.

[176] Jian W, Xu H-G, Chen J, Xu Z-X, Levitt JM, Stanley JA, Yang ES, Lerner SP, Sonpavde G. Activity of CEP-9722, a poly (ADP-ribose) polymerase inhibitor, in urothelial carcinoma correlates inversely with homologous recombination repair response to DNA damage. Anticancer Drugs 2014; 25(8): 878-886.

[177] Gorodetska I, Kozeretska I, Dubrovska A. BRCA Genes: the role in genome stability, cancer stemness and therapy resistance. J. Cancer 2019; 10(9): 2109-2127.

[178] Dréan A, Williamson CT, Brough R, Brandsma I, Menon M, Konde A, Garcia-Murillas I, Pemberton HN, Frankum J, Rafiq R, Badham N, Campbell J, Gulati A, Turner NC, Pettitt SJ, Ashworth A, Lord CJ. Modeling therapy resistance in brca1/2-mutant cancers. Mol Cancer Ther 2017; 16(9): 2022 LP-2034.

[179] Bohrer RC, Dicks N, Gutierrez K, Duggavathi R, Bordignon V. Double-strand DNA breaks are mainly repaired by the homologous recombination pathway in early developing swine embryos. FASEB J Off Publ Fed Am Soc Exp Biol 2018; 32(4): 1818-1829.

[180] Germano G, Amirouchene-Angelozzi N, Rospo G, Bardelli A. The clinical impact of the genomic landscape of mismatch repairdeficient cancers. Cancer Discov 2018; 8(12): 1518 LP-1528.

[181] Kaniecki K, De Tullio L, Greene EC. A change of view: homologous recombination at single-molecule resolution. Nat Rev Genet 2018; 19(4): 191-207.

[182] Zhang J. The role of BRCA1 in homologous recombination repair in response to replication stress: significance in tumorigenesis and cancer therapy. Cell Biosci 2013; 3(1): 11.

[183] Mengwasser KE, Adeyemi RO, Leng Y, Choi MY, Clairmont C, D'Andrea AD, Elledge SJ. Genetic screens reveal FEN1 and APEX2 as BRCA2 synthetic lethal targets. Mol Cell 2019; 73(5): 885-899.

[184] Gröschel S, Hübschmann D, Raimondi F, Horak P, Warsow G, Fröh- lich M, Klink B, Gieldon L, Hutter B, Kleinheinz K, Bonekamp D, Marschal O, Chudasama P, Mika J, Groth M, Uhrig S, Krämer S, Heining C, Heilig CE, Richter D, Reisinger E, Pfütze K, Eils R, Wolf S, von Kalle C, Brandts C, Scholl C, Weichert W, Richter S, Bauer S, Penzel R, Schröck E, Stenzinger A, Schlenk RF, Brors B, Russell RB, Glimm H, Schlesner M, Fröhling S. Defective Homologous recombination DNA repair as therapeutic target in advanced chordoma. Nat Commun 2019; 10(1): 1635.

[185] Jaspers JE, Kersbergen A, Boon U, Sol W, van Deemter L, Zander SA, Drost R, Wientjens E, Ji J, Aly A, Doroshow JH, Cranston A, Martin NMB, Lau A, Connor MJ, Ganesan S, Borst P, Jonkers J, Rottenberg S. Loss of 53BP1 causes PARP inhibitor resistance in Brca1-mutated mouse mammary tumors. Cancer Discov 2013; 3(1): 68 LP-81.

[186] Vaidyanathan A, Sawers L, Gannon A-L, Chakravarty P, Scott AL, Bray SE, Ferguson MJ, Smith G. ABCB1 (MDR1) Induction Defines a Common Resistance Mechanism in Paclitaxel- and olaparibresistant ovarian cancer cells. Br J Cancer 2016; 115(4): 431-441.

[187] Edwards SL, Brough R, Lord CJ, Natrajan R, Vatcheva R, Levine DA, Boyd J, Reis-Filho JS, Ashworth A. Resistance to therapy caused by intragenic deletion in BRCA2. Nature 2008; 451(7182) 1111-1115.

[188] Sakai W, Swisher EM, Karlan BY, Agarwal MK, Higgins J, Friedman C, Villegas E, Jacquemont C, Farrugia DJ, Couch FJ, Urban N, Taniguchi T. Secondary mutations as a mechanism of cisplatin resistance in BRCA2-mutated cancers. Nature 2008; 451(7182): 11161120 .

[189] Swisher EM, Sakai W, Karlan BY, Wurz K, Urban N, Taniguchi T. Secondary BRCA1 mutations in BRCA1-mutated ovarian carcinomas with platinum resistance. Cancer Res 2008; 68(8): 2581-2586.

[190] Bouwman P, Aly A, Escandell JM, Pieterse M, Bartkova J, van der Gulden H, Hiddingh S, Thanasoula M, Kulkarni A, Yang Q, Haffty BG, Tommiska J, Blomqvist C, Drapkin R, Adams DJ, Nevanlinna H, Bartek J, Tarsounas M, Ganesan S, Jonkers J. 53BP1 loss rescues BRCA1 deficiency and is associated with triple-negative and BRCAmutated breast cancers. Nat Struct Mol Biol 2010; 17(6): 688-695.

[191] Pascal JM, Ellenberger T. The rise and fall of poly(ADP-ribose): an enzymatic perspective. DNA Repair (Amst). 2015; 32: 10-16.

[192] Feng X, Koh DW. Chapter five-roles of poly(ADP-ribose) glycohydrolase in DNA damage and apoptosis. In: Jeon KWBT-IR of C and MB (ed). vol. 304. Academic Press 2013; 227-281.

[193] Gogola E, Duarte AA, de Ruiter JR, Wiegant WW, Schmid JA, de Bruijn R, James DI, Guerrero Llobet S, Vis DJ, Annunziato S, van den Broek B, Barazas M, Kersbergen A, van de Ven M, Tarsounas M, Ogilvie DJ, van Vugt M, Wessels LFA, Bartkova J, Gromova I, Andújar-Sánchez M, Bartek J, Lopes M, van Attikum H, Borst P, Jonkers J, Rottenberg S. Selective loss of PARG restores PARylation and counteracts PARP inhibitor-mediated synthetic lethality. Cancer Cell 2018; 33(6): 1078-1093.e12.

[194] Murai J, Huang SN, Das BB, Renaud A, Zhang Y, Doroshow JH, Ji J, Takeda S, Pommier Y. Trapping of PARP1 and PARP2 by clinical PARP inhibitors. Cancer Res 2012; 72(21): 5588-5599.

[195] Mweempwa A, Wilson M. Mechanisms of resistance to PARP inhibitors-an evolving challenge in oncology. Cancer Drug Resist 2019.

[196] Thomas A, Murai J, Pommier Y. The evolving landscape of predictive biomarkers of response to PARP inhibitors. J Clin Invest 2018; 128(5): 1727-1730.

[197] Pettitt SJ, Rehman FL, Bajrami I, Brough R, Wallberg F, Kozarewa I, Fenwick K, Assiotis I, Chen L, Campbell J, Lord CJ, Ashworth A. A genetic screen using the PiggyBac transposon in haploid cells identifies Parp1 as a mediator of olaparib toxicity. PLoS One 2013; 8(4): e61520-e61520. 